UNIVERSIDADE DE SÃO PAULO

Faculdade de Filosofia, Ciências e Letras de Ribeirão Preto

Departamento de Psicologia e Educação

Programa de Pós-graduação em Psicobiologia

\title{
EFEITOS DA LESÃO COLINERGICA ESPECÍFICA DO NÚCLEO SEPTAL MEDIAL NO COMPORTAMENTO EXPLORATÓRIO DE RATOS NO LABIRINTO EM CRUZ ELEVADO EM UM PARADIGMA TESTE-RETESTE.
}

Marisol Lamprea Rodríguez

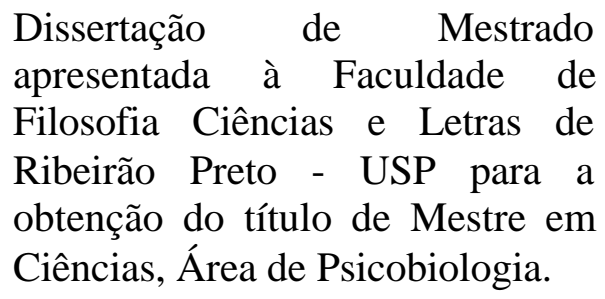

Ribeirão Preto - SP

1999 
UNIVERSIDADE DE SÃO PAULO

Faculdade de Filosofia, Ciências e Letras de Ribeirão Preto

Departamento de Psicologia e Educação

Programa de Pós-graduação em Psicobiologia

\section{EFEITOS DA LESÃO COLINERGICA ESPECÍFICA DO NÚCLEO SEPTAL MEDIAL NO COMPORTAMENTO EXPLORATÓRIO DE RATOS NO LABIRINTO EM CRUZ ELEVADO EM UM PARADIGMA TESTE-RETESTE.}

Marisol Lamprea Rodríguez

Orientador: Prof. Dr. Silvio Morato

Ribeirão Preto - SP

1999 


\section{Conteúdo}

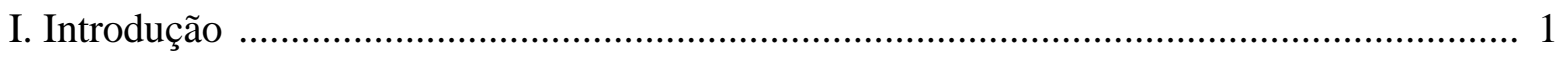

A. Sistema Septo-Hipocampal: Anatomia ….................................................... 1

1. Considerações Gerais ......................................................................... 1

2. Visão Anatômica e Funcional do Septo e do Hipocampo .......................... 2

3. Sistema Colinérgico .................................................................................... 5

B. Sistema Septo-Hipocampal e Exploração ...................................................... 7

1. Comportamento Exploratório: Considerações Gerais .............................. 7

2. Sistema Septo-Hipocampal e Comportamento Exploratório ................... 10

C. Sistema Septo-Hipocampal e Memória …......................................................... 12

1. Aprendizagem e Memória: Considerações Gerais .................................. 12

2. Memória Espacial .............................................................................. 14

3. Memória Espacial e Sistema Septo-Hipocampal ................................. 15

D. Sistema Septo-Hipocampal e Ansiedade ........................................................ 18

1. Ansiedade: Considerações Gerais ........................................................ 18

2. Sistema Septo-Hipocampal e Ansiedade .............................................. 20

E. O Labirinto em Cruz Elevado como Modelo Experimental

de Comportamento Exploratório, Ansiedade e Memória ............................. 23

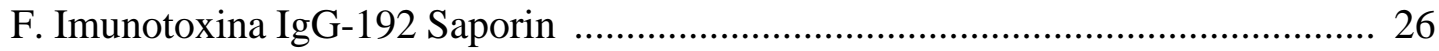

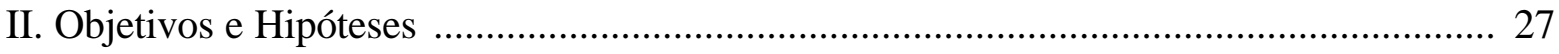

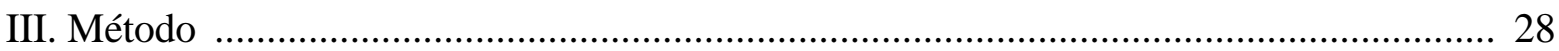

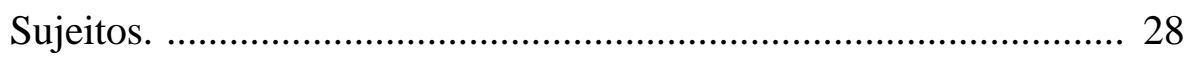

Equipamento …............................................................. 28

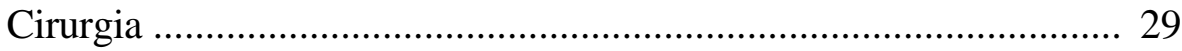

Procedimento ......................................................................... 29

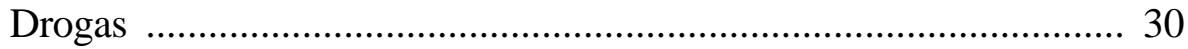

Análise bioquímica …............................................................... 31

Analise estatística ....................................................................... 32

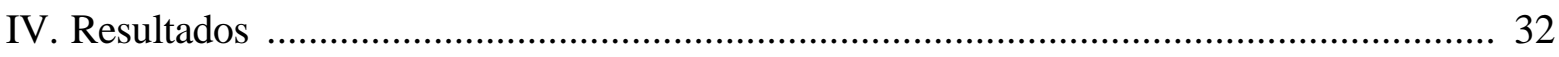

1. Análise Bioquímica .................................................................... 32

Atividade da acetilcolinesterase .................................................. 33

2. Análise Comportamental dos Totais de Respostas no Teste e Reteste .... 34 
Atividade Geral 34

Comportamentos associados com a ansiedade 38

Outros comportamentos 40

3. Análise Comportamental da Primeira Sessão Minuto a Minuto 43

Atividade geral 43

Comportamentos associados com a ansiedade 47

Outros comportamentos 49

V. Discussão 53

Análise bioquímica 53

Atividade geral 53

Comportamentos associados à ansiedade 55

Outros comportamentos 57

Análise minuto a minuto da primeira sessão 59

VI. Conclusões Gerais 62

VII. Referências Bibliográficas 66

VIII. Apêndice 74 


\section{SUMÁRIO}

O presente estudo investigou o efeito da lesão imunotóxica colinérgica específica do núcleo septal medial sobre o comportamento exploratório de ratos no labirinto em cruz elevado, em um paradigma teste-reteste, com analise minuto a minuto da primeira sessão. Uma análise bioquímica detectou uma diminuição da atividade da acetilcolinesterase no hipocampo, septo e córtex dos animais lesados com a toxina IgG-192 saporin (475 ng/ $\mu \mathrm{l})$ mas não nos animais com lesão fictícia ou nos controle. Não se encontraram diferenças significativas entre os grupos quanto aos comportamentos associados com a atividade locomotora (entradas nos braços fechados, entradas totais e distância percorrida), nem aos associados com a ansiedade (frequiência de entradas e tempo gasto nos braços abertos) nem tampouco os outros comportamentos analisados (esticar-se, levantar-se, mergulhar a cabeça e limpar-se), quando consideradas as sessões individualmente. Na comparação entre primeira e segunda sessões, os animais do grupo lesado não diminuíram a atividade exploratória durante a segunda sessão ao contrário dos animais dos grupos controle e de lesão fictícia. Um efeito semelhante foi observado nos comportamentos associados com a ansiedade e nos outros comportamentos registrados. Finalmente, uma análise minuto a minuto mostrou uma queda significativa ao longo da primeira sessão nas medidas de atividade locomotora, nos comportamentos associados com a ansiedade e nos outros comportamentos, nos animais dos grupos controle e com lesão fictícia, mas não nos animais lesados. Os resultados indicam um papel modulador da via colinérgica septohipocampal na atividade exploratória e nos processos de armazenamento e recuperação de informação, mas não na modulação da ansiedade, tal como avaliada no labirinto em cruz elevado. 


\begin{abstract}
The effect of a specific immunotoxic cholinergic lesion of the septal nucleus on exploratory behavior displayed by rats in the elevated plus maze was investigated. A five-minute test-retest approach with minute by minute analysis of the first session was used. Biochemical analyses detected a decrease in cholinesterase activity in the hippocampus, septum and cortex of animals lesioned with IgG-192 saporin (475 ng/ $\mu \mathrm{l})$ when compared with controls or sham lesioned animals. No statistical differences were found between groups in terms of behaviors associated with either locomotive activity (closed arms entries, total entries and distance percorred), anxiety (entries and time spent in the open arms) or the other behaviors recorded (stretching, rearing, head dipping and grooming). Lesioned animals did not decrease their exploratory activity in the second session as did controls and sham lesioned animals. The same was true for behaviors associated with anxiety. The minute by minute analysis showed a significant drop in exploratory as well as in anxiety associated behaviors along the first session. Results indicated a modulatory role for the cholinergic septo-hippocampal pathway in exploratory activity and its relation with storage and retrieval information processes but not for the modulation of anxiety as measured in the elevated pluz-maze.
\end{abstract}




\section{I N T R O D U Ç $\tilde{A}$ O}

\section{A. SISTEMA SEPTO-HIPOCAMPAL: ANATOMIA}

\section{$\underline{1 . \text { Considerações Gerais }}$}

O sistema septo-hipocampal, isto é, a comunicação entre o núcleo septal medial e o hipocampo, tem recebido particular atenção por seu papel preponderante em diversas funções emocionais e cognitivas (Messulam, 1995; Pesold e Treit, 1996; Walsh et al., 1996). Desde começo do século, o septo tem sido considerado uma estrutura privilegiada pela sua localização central no prosencéfalo dos mamíferos. Dado que se desenvolve dentro da parte dorsal da lâmina terminal, rostral ao foramen interventricular, o septo possui a capacidade de comunicação com partes importantes do telencéfalo, como o hipocampo e a amígdala, e com duas partes do diencéfalo: o hipotálamo e o complexo habenular. Assim, apesar do seu reduzido tamanho no cérebro dos primatas, a região septal tem sido objeto de extenso estudo. (Swanson, 1978).

A relação básica entre o septo e o hipocampo é conhecida desde a época de Honneger, no final do século passado (Swanson, 1978). Estudos de Lewis e Shute (1967), usando métodos histoquímicos para identificação da acetilcolinesterase, demostraram que a área composta pelo septo medial e banda diagonal apresenta um conjunto de neurônios que contêm acetilcolinesterase. A partir do resultado de experimentos com lesões específicas, esses autores concluíram que estas células projetam-se ao hipocampo. Estudos posteriores têm definido de maneira mais cuidadosa as conexões aferentes e eferentes do sistema septo-hipocampal, assim como 
sua função na mediação do comportamento (Gray, 1982, 1984; Freund e Antal, 1988;

Wiley et al., 1991; Walsh et al., 1996)

\section{Visão Anatômica e Funcional do Septo e do Hipocampo}

Na maioria dos mamíferos, o desenvolvimento do corpo caloso propicia uma separação entre o septo e o hipocampo, embora eles mantenham-se ligados através do fórnice. Com base em critérios de desenvolvimento, conexidade e citoarquitetura, o septo pode ser dividido em quatro partes principais: (1) a porção medial, que se projeta para o hipocampo; (2) a porção lateral, que recebe aferências do mesmo; (3) a divisão ventral, que compreende o núcleo basal da estria terminal (relacionada anatômicamente com a amígdala); e (4) a divisão posterior, que inclui os núcleos habenulares e interpedunculares, que se relacionam com o hipocampo. A porção medial contém uma variedade de neurônios com axônios de diferentes comprimentos. Convencionalmente, esta área tem sido dividida em núcleo septal medial e núcleo vertical da banda diagonal de Broca. Ambos os núcleos comunicam-se densamente com o complexo hipocampal. Já em 1966, Raisman relatou que o núcleo septal medial comunicava-se com o hipocampo e com o giro denteado, usando acetilcolina como neurotransmissor principal. Trabalhos posteriores, com técnicas mais avançadas de transporte retrógrado (Meibach e Siegel, 1977), incluíram os núcleos da banda diagonal de Broca no complexo que se projeta para o hipocampo.

Igualmente, demostraram a existência de uma relação topográfica entre o complexo composto pelo núcleo septal medial e núcleo basal da banda diagonal de Broca e o hipocampo. Ao que parece, as regiões mais mediais do núcleo septal medial projetam-se ao hipocampo rostral, enquanto as porções laterais e áreas adjacentes enviam fibras para regiões progressivamente mais caudais e ventrais da formação 
hipocampal. Inicialmente, pensava-se que estas conexões eram de carater ipsilateral mas estudos posteriores, como o de Lynch e cols (1972), demostraram a existência de conexões contralaterais.

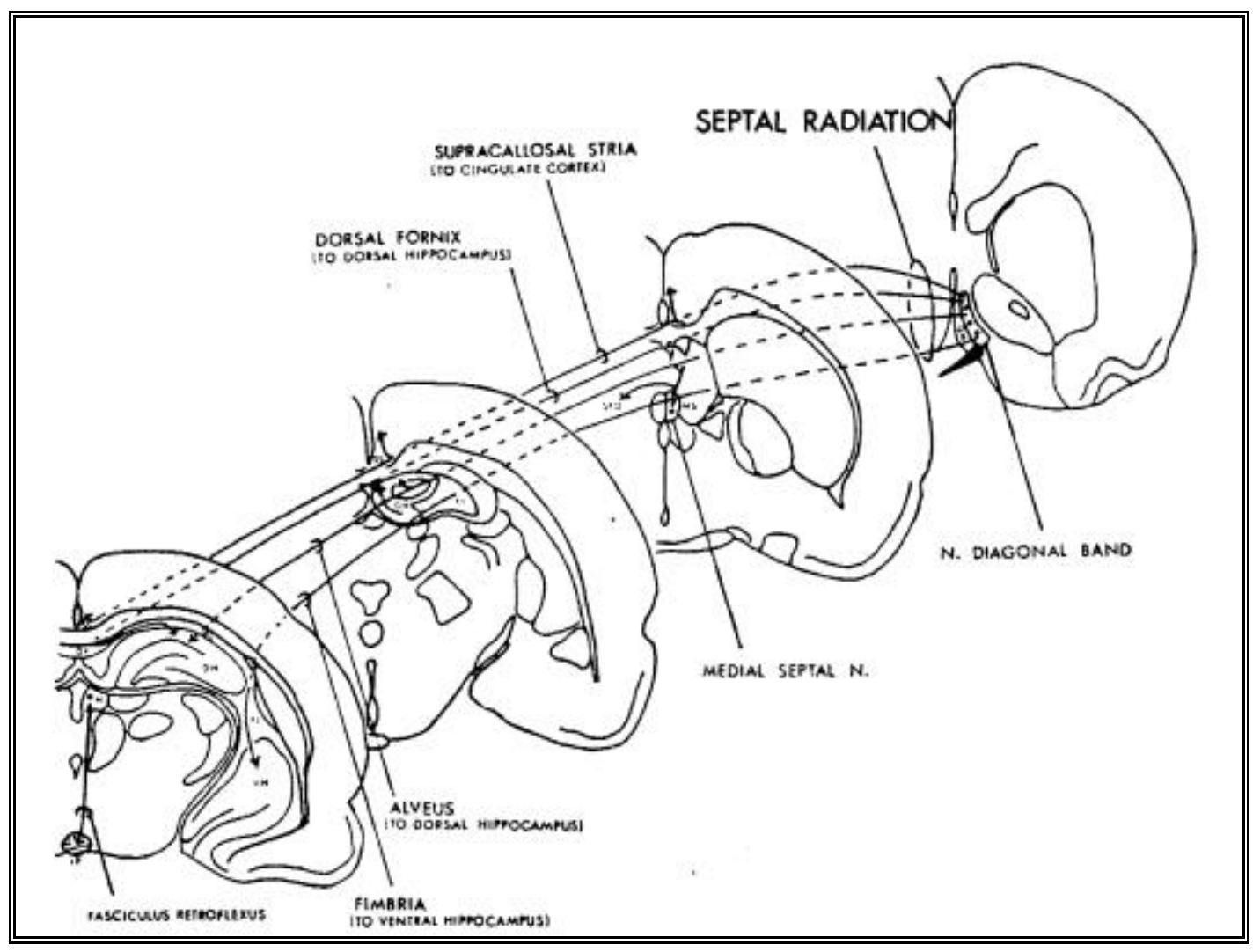

Quadro 1: Radiação septal colinérgica originada no núcleo septal medial e núcleo vertical da banda diagonal e que se projeta ao córtex cingulado, hipocampo e alveus. (Modificado de Lewis e Shute, 1967).

Mais recentemente, na década de 80 , vários autores relataram a existência de neurônios GABAérgicos oriundos do núcleo septal medial, que alcançam interneurônios no hipocampo (Kohler e Srebro, 1980; Freund e Antal, 1988). Atualmente sabe-se que aproximadamente o $50 \%$ das projeções septo-hipocampais utilizam acetilcolina como neurotransmissor, enquanto o $50 \%$ restantes estão repartidos em neurônios GABAérgicos e de outros tipos (Barone et al., 1991; Leranth et al., 1992). Estas projeções terminam nos corpos ou dendritos das células primárias 
ou nos interneurônios do hipocampo, os quais regulam a transmissão inibitória das células primárias (Frotscher e Leranth, 1985; Freund e Antal, 1988; Mizumori et al., 1992). Essa localização estratégica permite influências modulatórias precisas na atividade elétrica do hipocampo.

O sinal elétrico mais relevante que pode ser registrado no hipocampo é chamado de ritmo teta $(5-10 \mathrm{~Hz})$, e durante os últimos 30 anos tem-se estudado a relação desse ritmo com o comportamento. O ritmo teta tem sido associado com o estado de alerta (Wenk, 1997), assim como com aprendizagem e memória (Walsh et al., 1996), atenção (Wenk, 1997) e mais recentemente com a motricidade. Neste contexto, o ritmo teta hipocampal parece estar envolvido na inibição geral dos sistemas não utilizados durante o comportamento motor ou durante a imobilidade característica do estado de alerta nos mamíferos (Vinogradova, 1995; Oddie e Bland, 1998; Partlo e Sainsbury, 1996). A integridade da área compreendida pelo núcleo septal medial e pelo núcleo horizontal da banda diagonal e suas conexões eferentes é indispensável para a modulação da atividade elétrica no hipocampo (incluindo a modulação do ritmo teta), assim como para a aprendizagem de tarefas espaciais (Mizumori et al., 1990). O efeito primário dessas projeções nos neurônios hipocampais (células piramidais e não piramidais), é abolir a inibição induzida pelo GABA. De fato, quase dois terços dos neurônios piramidais do hipocampo são inibidos tonicamente pela estimulação sensorial, a qual evoca ritmo teta eletroencefalográfico (Vinogradova, 1995). Vários estudos têm examinado a contribuição das aferências septais na função hipocampal, observando os efeitos de lesões permanentes ou de fármacos na fisiologia do hipocampo (Winson, 1978; Miller e Best, 1980; Buzsaki et al., 1983; Foster et al., 1988; Mizumori et al., 1992). Partlo e Sainsbury (1996) demonstraram que a lesão eletrolítica do núcleo septal medial aboliu o ritmo teta no hipocampo e no núcleo 
mediano da rafe. Por outro lado, a injeção local do agonista GABAérgico muscimol na área que inclui o núcleo septal medial e o núcleo horizontal da banda diagonal eliminou totalmente o ritmo teta no hipocampo (Bland et al., 1996). Igualmente, a infusão intraseptal de procaína (um anestésico local) aboliu a atividade teta no hipocampo, assim como o comportamento de correr induzido pela estimulação elétrica do hipotálamo posterior. Já a infusão intra-septal do antagonísta muscarínico atropina eliminou o ritmo teta no hipocampo observado antes do inicio de comportamentos de defesa do alimento (Oddie e Bland, 1998). Finalmente, a injeção intracerebroventricular da toxina IgG-192-saporin, que elimina quase completamente os neurônios colinérgicos do prosencéfalo basal, produziu irregularidades no ritmo teta do hipocampo, mas não o eliminou completamente (Bassant et al., 1995). Mais recentmente (Apartis et al., 1998) foi relatado que a lesão dos neurônios colinérgicos do núcleo septal media e núcleo da banda diagonal com a mesma toxina reduziu a atividade rítmica nessa área. Essa atividade está envolvida na geração do ritmo teta hipocampal. Esses resultados sugerem que a projeção septo-hipocampal colinérgica participa na modulação da atividade elétrica do hipocampo, porém não se pode desconhecer a participação de projeções septo-hipocampais de outros tipos (como GABAérgicas).

\section{$\underline{\text { 3. Sistema Colinérgico }}$}

Identificada como o transmissor da junção neuromuscular, sinapses parasimpáticas e o principal transmissor nos gânglios autônomos, a acetilcolina começou a receber considerável atenção como um potencial neurotransmissor central. Baseados na sua distribuição irregular dentro do sistema nervoso central, bem como na observação do acentuado efeito comportamental da administração central de diversas 
drogas colinérgicas, vários autores consideraram a possibilidade de que a acetilcolina podia também ser um neurotransmissor central. No final da década de 50 e começo da de 60, Eccles e colaboradores demonstraram que a excitação recorrente dos neurônios de Renshaw na medula espinhal era sensível aos antagonistas colinérgicos nicotínicos; também se observou que essas células possuíam receptores para a acetilcolina (Bloom, 1996; Taylor, 1996). Através da combinação de estudos imunocitoquímicos da colina acetiltransferase (a enzima que sintetiza a acetilcolina) e de estudos de hibridização in situ para a detecção de neurônios que expressam subunidades de receptores colinérgicos foram caracterizados oito tipos de agrupamentos de neurônios colinérgicos e suas vias (Messulam, 1995). Dois desses agrupamentos de neurônios originam-se na ponte e constituem a principal projeção colinérgica ao tálamo e corpo estriado, enquanto dois outros, originados na medula, projetam-se para as regiões mesencefálicas e do tronco cerebral. Os quatro grupos restantes de corpos celulares, originados no prosencéfalo basal (septo medial e núcleo basal de Meynert), projetamse para o neocórtex, formação hipocampal e bulbo olfatório (Messulam, 1995). Enquanto o cérebro dos roedores apresenta neurônios colinérgicos intrínsecos no neocórtex, os primatas não exibimos esse tipo de neurônios (Messulam, 1995). Na maioria das regiões do sistema nervoso central, os efeitos da acetilcolina são mediados pela ação conjunta de receptores de tipo nicotínico e muscarínico. Cinco tipos de receptores colinérgicos muscarínicos (M1 a M5) foram reconhecidos até o presente, três dos quais já foram farmacológicamente caracterizados, dois dos quais tem recebido maior atenção (Messulam, 1995). Através do uso de toxinas seletivas e de análises auto-radiográficas, juntamente com estudos de ligantes específicos, foi constatada a presença de receptores muscarínicos dos tipos M1, M2 e M4 no hipocampo, no septo medial e no núcleo vertical da banda diagonal (Ehlert et al., 1995; 
Jerusalinsky et al., 1998). A atividade desses receptores muscarínicos tem sido associada a funções mnemônicas e cognitivas (Vannucchi et al., 1997; Jerusalinsky et al., 1997, 1998, Hatcher, et al 1998).

Os potenciais pós-sinápticos produzidos pela acetilcolina são de curta duração, já que a membrana pós-sináptica dessas sinapses contêm a enzima acetilcolinesterase, a qual decompõe a acetilcolina nos elementos que a constituem: colina e ácido acético. Já que nenhuma dessas duas substâncias é capaz de ativar os receptores pós-sinápticos por si só, o potencial pós-sináptico é terminado uma vez que as moléculas de acetilcolina são decompostas. Uma só molécula de acetilcolinesterase pode decompor mais de cinco mil moléculas de acetilcolina por segundo (Carlson, 1994). Depois da decomposição da acetilcolina na membrana pós-sináptica, a colina é recaptada pelo botão terminal, onde é convertida novamente em acetilcolina; a acetilcolinesterase também está presente no citoplasma dos botões terminais, onde inativa a acetilcolina que fica fora das vesículas sinápticas (Carlson, 1994). Todos os neurônios colinérgicos do núcleo septal medial, núcleo vertical da banda diagonal e núcleo basal de Meynert contêm acetilcolinesterase nos seus corpos, axônios e dendritos, e a presença e nível dessa enzima é utilizada como indicador de atividade colinérgica, como por exemplo, em estudos investigando a lesão causada pela imunotoxina IgG 192-saporin no sistema colinérgico prosencefálico (Torres et al., 1994; Walsh et al., 1996; Janis et al., 1998; Chapell et al., 1998).

\section{B. SISTEMA SEPTO-HIPOCAMPAL E EXPLORAÇÃO}

\section{Comportamento Exploratório: Considerações Gerais}


O comportamento exploratório é vital à sobrevivência da maior parte dos animais, e tem sido estudado em diversas espécies, desde insetos (Barnett, 1958) até macacos (Butler, 1953). Porém os estudos mais amplos e detalhados foram realizados com roedores, dado seu caráter altamente exploratório, tanto em estado natural, como em cativeiro. Já no final do século passado descreveu-se a incessante atividade de ratos juvenis como um indicador de curiosidade, e enfatizou-se que a conduta exploratória desenvolvida plenamente a partir das três semanas de idade, não era um mero reflexo de fome (Barnett, 1958). Os primeiros estudos sobre comportamento exploratório realizados nesse século já mostravam que os movimentos exploratórios dos ratos freqüentemente são acompanhados de aprendizagem topográfica independentemente de qualquer recompensa (para uma revisão, Barnett, 1958). A partir da década de cinqüenta, podem encontrar-se estudos complementares provenientes da área de Zoologia, segundo os quais ratos selvagens apresentam comportamento exploratório similar ao de animais de laboratório, quando colocados em ambientes novos (Barnett, 1956; Barnett, 1958). Na mesma década, popularizou-se um debate sobre as motivações que poderiam dar origem ao comportamento exploratório. Barnett (1956) observou dois tipos de situações que evocavam movimentos generalizados em animais selvagens: (1) quando obtêm acesso a uma área nova e (2) quando uma situação não familiar é introduzida em um ambiente já conhecido. Já em ambientes familiares, os ratos exploraram com menor intensidade do que em ambientes novos, aumentando a exploração quando os animais estavam saciados. Esses movimentos generalizados podem ser distinguidos daqueles destinados a suprir uma necessidade fisiológica (como a fome ou a sede), sendo que também eles tem uma origem fisiológica ainda não totalmente compreendida. 
Adicionalmente ao estudo das motivações internas, têm-se analisado os estímulos externos que influenciam o comportamento exploratório. Em experimentos com labirintos em $\mathrm{T}$, no qual o sujeito tem que escolher um dentre dois braços possíveis, numa segunda sessão, o animal mostrará uma forte tendência em escolher o braço não visitado na primeira sessão (Barnett, 1956). Berlyne (1950) mostrou que ratos passam mais tempo explorando objetos novos do que objetos já conhecidos. Entretanto, se submetidos a um ambiente conhecido, passavam menos tempo explorando-o. Thompson e Solomon (1954) já tinham encontrado achados semelhantes aos de Berlyne (1956), demonstrando que ratos expostos a um novo padrão visual exploram mais que ratos expostos a um padrão visual já conhecido. Montgomery (1955) demonstrou que o tempo de exploração gasto em um segundo labirinto é uma função da sua similaridade com o primeiro. Trabalhos dessa natureza permitiram concluir que o comportamento exploratório não é, em si mesmo, apenas o resultado de uma mudança de um ambiente para outro, mas resulta de uma motivação específica, induzida pela presença de informações novas ou estimulantes. A motivação para explorar um área nova é tão forte que pode ser usada como reforço em experimentos de aprendizagem, fazendo com que animais com fome ou sede prefiram explorar ao invés de saciarem suas necessidades (Zimbardo e Montgomery, 1957).

Observa-se, porém, uma situação contrastante quando os animais são confrontados com uma alteração em um ambiente conhecido previamente. Foi relatado (Barnett, 1958) que ratos selvagens apresentaram uma clara tendência em esquivar-se de objetos ou alimentos novos colocados em ambientes familiares. Essa tendência à esquiva também foi observada em ratos criados em cativeiro, porém com intensidade muito menor. As reações contraditórias frente à novidade, descritas anteriormente, foram explicadas por Berlyne (1951). Esse autor afirma que a novidade pode ser 
interpretada de maneira distinta pelo animal segundo a situação. Quando uma situação se apresenta como inteiramente nova para o sujeito, predominará a tendência exploratória. Por outro lado, quando ocorre um contraste entre o que o animal espera do ambiente e o que se lhe apresenta, a tendência predominante é a de esquivar-se ou fugir. Essas duas tendências motivacionais são a base de quase todos os modelos experimentais de comportamento exploratório e representam o ponto de partida no estudo contemporâneo da exploração e da curiosidade. Porém, a partir da década de 60 são poucos os trabalhos dedicados exclusivamente ao estudo do comportamento exploratório e sua fisiologia, porem encontram-se alguns trabalhos que utilizam a exploração como índice comportamental dentro do estudo de outros comportamentos (Flicker e Geyer, 1982; Monmaur et al., 1997).

\section{Sistema Septo-Hipocampal e Comportamento Exploratório}

Já na década de 60 encontram-se estudos que avaliam o efeito de lesões do sistema septo-hipocampal sobre o comportamento exploratório de ratos. Em 1965, Nielson e colaboradores realizaram lesões eletrolíticas não específicas dos núcleos septais com a finalidade de avaliar seus efeitos em vários índices comportamentais, dentre eles o comportamento exploratório em um ambiente novo. Durante dois dias consecutivos, os sujeitos lesados mostraram uma tendência exploratória significativamente maior em relação ao grupo controle. Nas décadas de 70 e 80, encontram-se as propostas mais sistemáticas tentando esclarecer a relação entre o sistema septo-hipocampal e o comportamento exploratório. Em 1978, O'Keefe e Nadel formularam sua teoria do hipocampo como um mapa cognitivo, na qual propunham o sistema septo-hipocampal como o substrato dos mapas ambientais formados por um animal após explorar um ambiente. Nessa teoria, os autores oferecem uma explicação 
para a tendência exploratória observada em animais expostos a ambientes novos. A proposta básica é a de que o hipocampo (e em geral o sistema septo-hipocampal) funciona como um mapa cognitivo formado a partir da informação sensorial recebida, levando à identificação de objetos próprios do ambiente novo, bem como à própria localização do sujeito dentro desse ambiente. Desse ponto de vista, a exploração é considerada um conjunto de comportamentos que permitem a entrada de informações oriundas das partes do ambiente com características desconhecidas para o sujeito. ou que não correspondem a mapas anteriores. O propósito do comportamento exploratório seria então o de corrigir a representação prévia do ambiente, oferecendo informações novas para o mapa cognitivo (O'Keefe e Black, 1978). Esse padrão comportamental seria exibido pelos animais exclusivamente na presença de um ambiente novo. A informação oferecida por um ambiente familiar produz outro tipo de comportamentos (de aproximação e/ou de esquiva) que correspondem ao significado biológico que o ambiente representa para o animal. Segundo esta teoria, os animais atendem momentaneamente a aspectos já conhecidos do ambiente, os quais são previstos pelo mapa. Assim, a aparência de um evento biologicamente significativo produziria aproximação (e eventualmente consumação) ou esquiva. Porém, a atenção pode também ser detida em aspectos não previstos, ou novos, do ambiente. A investigação da discrepância entre o que o animal espera do ambiente, segundo o mapa, e os eventos inesperados ou novos, permite completar ou modificar o mapa, assim como eliminar características do ambiente já perdidas. A exploração seria então uma resposta direta à detecção de um "despareamento" (dismatching) pelo animal (O'keefe e Black, 1978).

Gray (1982) oferece uma explicação similar, acrescentando que a percepção da discrepância acima mencionada produz ansiedade no animal. Esse estado ansioso pode 
ser evidenciado pelo aumento no estado de alerta e pela inibição comportamental geral (Gray, 1984).

\section{SISTEMA SEPTO-HIPOCAMPAL E MEMÓRIA}

\section{$\underline{\text { 1. Aprendizagem e Memória: Considerações Gerais }}$}

A origem do estudo contemporâneo da localização dos processos mnemônicos no SNC inspirou-se no estudo de outro processo cognitivo. Em 1861, Paul Broca (citado por Kandel et al, 1995) descobriu que a lesão restrita da região posterior do lóbulo frontal produzia um déficit lingüístico. A partir dessa localização da linguagem, os neurocientistas começaram a procura pela localização da memória. O resultado geral foi o estabelecimento de múltiplos sistemas de memória "armazenados" em diferentes circuitos neuronais (Kandel, 1995; Fuster, 1995).

Com base em estudos clínicos e experimentais, foi proposta a existência de dois grandes sistemas de armazenamento e recuperação de informação, um deles relacionado com fatos e eventos - memória declarativa - e o outro relacionado com habilidades sensoriais motoras e operações mentais - memória não-declarativa (Fuster, 1995). Evidências provenientes de pacientes amnésicos e de dados experimentais sugerem que o armazenamento e recuperação da memória declarativa incluem diferentes mecanismos cerebrais no lóbulo temporal. Por sua parte, o substrato para o armazenamento da memória não-declarativa foi proposto como residindo nas áreas motoras do córtex, no cerebelo e nos gânglios basais (Atkinson e Shiffrin, 1968). 
Do ponto de vista da persistência temporal dos eventos armazenados, foi proposto que a informação sensorial, armazenada em alguma classe de memória sensorial depois da codificação inicial, pode ser transferida a uma memória de curto prazo, com capacidade limitada, e depois à memória de longo prazo, de capacidade maior (Murdock, 1982; Atkinson e Shiffrin, 1968). Atualmente sabe-se que as memórias de curto prazo são mediadas por uma variedade de mudanças plásticas de curta duração na transmissão sináptica, tais como a inibição presináptica ou o armazenamento de informação em forma de atividade neuronal reverberante, mantida através de conexões de retroalimentação excitatória e inibitória entre os neurônios. A localização do circuito a ser ativado durante o armazenamento dependem da natureza da informação que está entrando através dos sentidos, do comportamento que se está levando a cabo nesse momento e do setor de memória de longo prazo associado a essa informação (Fuster, 1995). Tem-se proposto que o armazenamento de informação por longos prazos relaciona-se com modificações plásticas funcionais e persistentes no cérebro. Essa proposta foi avaliada através da análise de situações nas quais suspendese a atividade neuronal por anestesia profunda, anóxia ou congelamento do cérebro. Quando essas situações se apresentam, as memórias recentes são perturbadas, porém as memórias antigas não (Kandel, 1995).

A natureza persistente da memória parece refletir alterações de longo prazo nas conexões entre os neurônios, incrementando o numero de zonas ativas das terminações sinápticas, assim como o crescimento axonal dentro dos circuitos já estabelecidos. Quando as sinapses excitatórias do hipocampo e outras estruturas são intensa e repetitivamente estimuladas durante períodos curtos de tempo, apresentam um fortalecimento na sua eficácia que pode durar várias horas ou inclusive semanas após a indução. Esse fortalecimento dependente do uso foi chamado de potencialização 
de longo prazo - long term potentiation (Bliss e Lomo, 1973) e foi proposto que esse efeito fortalecedor funciona como um mecanismo celular para a formação de memória, principalmente por apresentar-se proeminentemente no hipocampo, o local onde se acredita ocorrer a consolidação das informações na memória de longo prazo (Swanson et al., 1982; Izquierdo e Medina, 1997). A potencialização de longo prazo é induzida a través da estimulação das fibras pré-sinápticas com um trem de pulsos de alta frequiência (na ordem de $100 \mathrm{~Hz}$ por segundo). Imediatamente após essa estimulação, a resposta da sinapse a estímulos elétricos individuais é fortalecida, sendo que esse incremento na resposta diminui nos minutos seguintes. Recentemente tem-se proposto

a existência de um mecanismo contrário ao de potencialização de longo prazo, a depressão de longo prazo, a qual participaria nos mecanismos mnemônicos equilibrando as redes neurais (Martínez e Derrick, 1996). Atualmente existe considerável evidência de que a ativação de receptores N-methyl-D-aspartato (um dos receptores para o aminoácido glutamato, provavelmente o neurotransmissor excitatório mais amplamente distribuído no sistema nervoso central) é responsável pela indução dos fenômenos de potenciação e depressão a longo prazo no hipocampo (Nicoll et al., 1988; Izquierdo et al., 1992; Izquierdo, 1994; Izquierdo e Medina, 1993, 1995, 1997).

\section{Memória Espacial}

Os experimentos de aprendizagem em humanos e outros animais, bem como os estudos clínicos de lesões cerebrais, têm produzido a maior parte das teorias atuais sobre memória. Vários pesquisadores criaram estratégias comportamentais tendentes à caraterização da memória em diversas espécies, sobretudo em roedores, aproveitando a natureza exploratória desses animais. Esses estudos têm levado à proposta da chamada 
memória espacial, descrita como a capacidade dos animais de criar "listas" de localizações espaciais escolhidas por eles durante o reconhecimento de um local, sendo essas listas susceptíveis de recuperação em situações posteriores (Olton et al., 1978). Desde a proposta inicial desse tipo de memória, o hipocampo tem sido apontado como uma estrutura crucial para esse fenômeno. Experimentos nos quais se lesa o hipocampo (ou seus aferentes) produzem déficits na aprendizagem e recuperação de tarefas de memória espacial (Olton, 1979; O'Keefe e Nadel, 1978; Rawlins e Olton, 1982).

\section{$\underline{\text { 3. Memória Espacial e Sistema Septo-Hipocampal }}$}

Estudos da década de 70 já mostravam o papel dos mecanismos colinérgicos na memória. Bloqueadores colinérgicos (por exemplo a escopolamina) aplicados sistemicamente perturbam a aprendizagem de tarefas espaciais aprendidas em intervalos curtos de tempo (memória de trabalho), enquanto compostos inibidores da acetilcolinesterase (por exemplo a fisostigmina), facilitam a execução dessas tarefas (Deutsch, 1971; Alpern, 1973). Resultados provenientes de estudos com humanos mostraram adicionalmente que a degeneração de neurônios colinérgicos prosencefálicos correlacionava-se com déficits cognitivos, particularmente no caso da demência senil do tipo Alzheimer (Whitehouse et al., 1982).

Estudos com ratos mostraram uma redução no número e tamanho de neurônios nos núcleos colinérgicos prosencefálicos (núcleo septal medial, núcleo basal magnocelular) de animais velhos (24 meses de idade), comparados com controles jovens ( 3 meses de idade). Esse fato foi relacionado com dificuldades na aprendizagem do labirinto aquático de Morris, onde os animais devem aprender a identificar a 
localização de uma plataforma em uma piscina circular, na qual podem subir para não ter que nadar (Fischer et al., 1989). Outros experimentos mostraram que a lesão do núcleo septal medial e do núcleo basal magnocelular altera tarefas de aprendizagem e memória, assim como tarefas de atividade motora (Gray e McNaughton, 1983). Finalmente, relatou-se que a destruição bilateral completa da fímbria e fórnice (principal conexão entre o septo e o hipocampo) produz um déficit severo e duradouro na execução de tarefas espaciais previamente aprendidas (labirinto radial de 4, 8 e 17 braços; Olton, 1979). Recentemente, esses achados foram confirmados com o uso de técnicas de lesão eletrolítica ou excito-tóxica, concluindo-se que o septo medial envia ao hipocampo informações integradas por uma variedade de estruturas mesencefálicas e límbicas, relacionadas com processos vegetativos e de atenção (Walsh, 1996). Os efeitos das lesões septo-hipocampais tem sido significativamente atenuadas com a aplicação intraperitonial pré-treino do ligando para o receptor colinérgico nicotínico ABT-418 (Decker et al., 1994), permitindo sugerir um papel modulador dos mecanismos colinérgicos da vía septo-hipocampal nos processos de armazenamento e recobro de informação espacial. Igualmente, foi relatada uma inibição da atividade do núcleo septal medial mediante a infusão local do benzodiazepínico clordiazepóxido a qual reduziu a atividade dos neurônios colinérgicos que se projetam ao hipocampo e produziu déficits tempo-dependentes em tarefas de memória de trabalho espacial (Chrobak et al., 1989; Walsh et al., 1993; Stackman e Walsh, 1995).

Estudos in vitro demonstraram que pode ser induzida uma atividade elétrica de tipo teta nos neurônios do hipocampo a partir da estimulação com agonistas colinérgicos. Esses mesmos fármacos facilitaram a potencialização de longo prazo induzida por estimulação elétrica de alta freqüência, sendo ambos os efeitos bloqueados pela aplicação do antagonista muscarínico atropina (Natsume e Kometani, 
1997). Os autores sugerem a existência de mecanismos muscarínicos facilitatórios da potencialização de longo prazo (Natsume e Kometani, 1997). Já estudos realizados in vivo demonstraram que a injeção intraseptal de doses amnésicas do agonista benzodiazepínico clordiazepóxido diminuem a resposta excitatória no giro denteado induzida pelo córtex entorrinhal, enquanto a injeção intraseptal do antagonista benzodiazepínico flumazenil fortalece a capacidade de resposta das células do giro denteado e facilita a potencialização de longo prazo induzida pela estimulação de alta freqüência (Stackman et al., 1996). Finalmente foi relatado que a projeção colinérgica septo-hipocampal pode fazer parte do mecanismo indutor da potenciação e depressão a longo término, já que tem se observado que a acetilcolina despolariza os neurônios piramidais no hipocampo, reduz a inibição proveniente de projeções GABAérgicas e regula a atividade glutamatérgica (Jerusalinski et al., 1997).

Uma nova estratégia para produzir dano permanente e seletivo das projeções colinérgicas do septo ao hipocampo surgiu com o desenvolvimento de uma imunotoxina que alcança especificamente os corpos dos neurônios colinérgicos dos núcleos prosencefálicos basais (Wiley, 1991). A infusão intraseptal dessa toxina produziu déficits dose-dependentes na execução de uma tarefa de despareamento retardado do modelo (delayed-non-match-to-sample) em um labirinto radial de oito braços, aprendida antes da lesão (Walsh et al., 1996). Resultados similares foram relatados por Shen e colaboradores (1996), usando o mesmo paradigma de desapareamento retardado do modelo. Esses mesmos autores, entretanto, não acharam efeito da lesão seletiva do núcleo septal medial em uma tarefa de memória de referência, sugerindo um papel seletivo da conexão entre o núcleo septal medial e o hipocampo em processos de memória espacial. 
A maioria dos experimentos descritos na literatura sobre o papel do sistema septo-hipocampal no armazenamento e recuperação da informação tem sido desenvolvida em ratos treinados em tarefas complexas, como pressão de uma alavanca, associação de informação espacial, nado em piscinas e outras. Existem poucos trabalhos onde as condições experimentais guardam alguma semelhança com o meio ambiente natural dos animais. Este fato pode de alguma maneira introduzir variações na interpretação dos resultados e na proposta de modelos para explicar fenômenos observados na natureza.

\section{SISTEMA SEPTO-HIPOCAMPAL E ANSIEDADE}

\section{Ansiedade: Considerações Gerais}

No repertório adaptativo da maior parte dos animais, os mecanismos de defesa ante situações de perigo têm particular importância. As reações de um animal quando confrontado com uma ameaça à sua integridade são altamente estereotipadas na maioria das espécies. Em um ambiente novo, potencialmente perigoso, os animais apresentam comportamentos de avaliação do risco potencial e, uma vez definido um perigo real, comportamentos de fuga ou luta contra o agressor (Blanchard et al., 1986, 1990; Blanchard e Blanchard, 1988, 1990; Graeff, 1990), sendo que essas respostas comportamentais são geralmente acompanhadas de intensas alterações neurovegetativas e hormonais (Graeff, 1989). Sob esse ponto de vista, a ansiedade pode ser considerada como um estado emocional subjetivo de apreensão ou tensão que pode ser vivenciada como desagradável ou ameaçadora, sendo que a ameaça pode ser 
representada por um estímulo que evoca uma resposta inata ou respostas aprendidas (para uma revisão, ver Setem, 1997).

A ansiedade pode diferenciar-se do medo pelas situações nas quais é desencadeada. Enquanto o medo seria desencadeado por situações específicas e evidentes de perigo e ameaça, a ansiedade seria desencadeada por situações onde o perigo é apenas potencial, vago e obscuro (Graeff, 1989). Diferente das outras desordens psiquiátricas, a ansiedade é uma emoção normal que serve como una resposta útil à vigilância, a uma ameaça ou a um estímulo aversivo, e pode existir tanto na forma de patológica como ser normalmente vivenciada (Nutt, 1990). Até um certo ponto, a ansiedade favorece o desempenho de tarefas motoras e cognitivas e é necessária para um bom desempenho em muitas situações da vida; entretanto, ela se torna patológica quando a resposta ao estímulo se torna exagerada, irracional ou perturbadora e interfere com o funcionamento normal do indivíduo (Pratt, 1992). Os tratamentos farmacológicos da ansiedade percorreram um longo caminho desde os primeiros tratamentos com brometos e barbitúricos até o surgimento de fármacos mais eficazes e menos tóxicos, como os benzodiazepínicos e outros ansiolíticos seletivos. Apesar de conhecer-se de maneira mais ou menos detalhada o modo de ação desses fármacos ansiolíticos, não se compreende ainda a totalidade de fenômenos fisiológicos que subjazem às reações de defesa normais ou patológicas observadas em todas as espécies animais (Graeff, 1994). Sabe-se atualmente que os mecanismos GABAérgicos estão profundamente implicados no controle da ansiedade. Porém, devido a extensa distribuição dessas projeções GABAérgicas no cérebro dos mamíferos, foi difícil a identificação das estruturas e sistemas específicos envolvidos no processo. Recentemente foram desenvolvidos modelos animais de ansiedade com a finalidade de responder a essas interrogações, e hoje se tem hipóteses mais 
consistentes. Acredita-se que a ação inibitória do GABA, cujo efeito e potencializado por drogas ansiolíticas benzodiazepínicas, afeta os neurônios originados nos núcleos da rafe, no mesencéfalo que projetam uma via ascendente, a qual alcança diversas estruturas límbicas (para uma revisão, ver Graeff, 1989; Graeff, 1994). Outro sistema neural identificado, integra (a) a matéria cinzenta que circunda o terceiro ventrículo, no diencéfalo — hipotálamo medial, (b) a matéria cinzenta periaquedutal mesencefálica, e (c) a amígdala, uma estrutura límbica intimamente ligada ao hipotálamo (Graeff et al., 1993; Tomaz et al., 1993; Zangrossi e Graeff, 1994; Viana et al., 1997). Esse sistema cerebral integra comportamentos de defesa desencadeados por estímulos ameaçadores. Os fármacos benzodiazepínicos inibem essas reações defensivas através da intensificação da ação moduladora tônica da neurotrasmissão GABAérgica (Graeff, 1989).

\section{Sistema Septo-Hipocampal e Ansiedade}

Os estudos sobre o papel das estruturas límbicas no controle das emoções começaram cedo neste século. Em 1937, James Papez propôs que o substrato cortical para as emoções seria um anel de córtex filogeneticamente antigo, que rodeia o tronco cerebral, uma região chamada de lóbulo límbico por Paul Broca. O sistema límbico é composto pelo giro parahipocampal e pelo córtex subjacente à formação hipocampal. A formação hipocampal inclui o hipocampo propriamente dito, o giro denteado e o subículo (Fuster, 1995). Papez argumentou que o hipotálamo (uma estrutura já reconhecida como moduladora das alterações neurovegetativas observadas em situações de perigo) comunica-se com áreas corticais superiores, de tal forma que a cognição e a emoção afetam-se reciprocamente. Esta idéia foi evidenciada no contexto 
clinico pela observação de pacientes com encefalite causada pelo vírus da raiva (o qual afeta o hipocampo), nos que se apresentavam profundas mudanças emocionais, incluindo ataques de terror e ira (Kandel et al., 1995).

Em 1937, Heinrich Kluver e Paul Bucy verificaram que a remoção bilateral do lóbulo temporal de macacos (incluindo à amígdala e a formação hipocampal) produzia uma dramática síndrome comportamental, caracterizada por extrema calma (sendo esses animais normalmente agressivos ao contato com humanos) e por hiper-oralidade e hipersexualidade. Adicionalmente, os animais mostravam-se extremamente reativos a estímulos visuais, falhando no reconhecimento de objetos familiares (Kandel et al., 1995)

Na década de 50, incluiu-se o septo entre as estruturas cuja estimulação ou lesão afetam a conduta emocional. Relatou-se que lesões septais gerais (incluindo tanto o núcleo septal medial quanto o septal lateral e estruturas adjacentes) em ratos produzem uma resposta exagerada de alerta e hiper-emocionalidade (Brady e Nauta, 1953, 1955). Outros investigadores descreveram que estas respostas reduzem-se na medida em que os animais entram em contato com os experimentadores, desaparecendo por completo 30 dias após a lesão (Nielson et al., 1965). Em 1973, Poplawski e Johnson descreveram um aumento do comportamento de submissão em ratos submetidos a lesão do núcleo septal medial, enquanto animais com lesão do núcleo septal lateral apresentavam elevada agressividade e hiper-emocionalidade. Trabalhos da década de 80 baseados nesses resultados iniciais, descreveram que ratos com lesão do núcleo septal lateral pareciam mais reativos a estímulos aversivos que ratos com lesão do núcleo septal medial, os quais não mostravam diferenças em relação ao grupo controle (Lee et al., 1988). Na mesma década de 80, Jeffrey Gray propôs que estímulos potencialmente aversivos (como ambientes novos, sinais de 
punição ou de não recompensa) produzem mudanças comportamentais (inibição comportamental, incremento do nível de alerta e incremento da atenção) coordenadas por um sistema de inibição comportamental, que seria afetado por fármacos ansiolíticos benzodiazepínicos. Nesse modelo, as funções do sistema inibitório são exercidas pelo sistema septo-hipocampal e estruturas que comunicam-se com ele, principalmente as aferências noradrenérgicas e serotoninérgicas (Gray, 1982, 1984).

Na década de 90, destacam-se os trabalhos do grupo de Treit, que tentam estabelecer o papel do sistema septo-hipocampal nos comportamentos observados em modelos animais de ansiedade. É interessante notar que em todos os seus trabalhos, são utilizados modelos nos quais o animal é colocado em situações semelhantes às naturais, que não requerem aprendizagem de respostas complexas e se baseiam nas reações normais dos animais frente a estímulos aversivos. Esses autores propuseram que o uso desses modelos procura eliminar um possível fator de confusão, presente nos estudos anteriores sobre função do septo na ansiedade (Treit, 1985, 1994; Pesold e Treit, 1996). Foi relatado que lesões excito-toxicas do septo completo produziam efeitos similares aos observados com o uso de drogas ansiolíticas injetadas perifericamente, no labirinto em cruz elevado (aumento na porcentagem de entradas e tempo de permanência nos braços abertos em relação ao grupo controle). Posteriormente, foi descrito um efeito ansiolítico no mesmo teste, após a infusão de fármacos benzodiazepínicos no septo (Pesold e Treit, 1992; Treit, 1994). Esses mesmos autores também encontraram efeito de "tolerância" para os efeitos ansiolíticos da lesão septal após duas exposições consecutivas ao labirinto em cruz elevado. O termo tolerância refere-se ao fenômeno descrito pelo grupo de Sandra File, segundo o qual os fármacos ansiolíticos não produzem mais o mesmo efeito de aumentar a atividade exploratória nos braços abertos em uma segunda exposição ao labirinto em 
cruz elevado (File, 1990, 1993; File et al., 1990, 1992). Em 1996, Pesold e Treit relataram que a lesão eletrolítica seletiva do núcleo septal medial produziu um efeito do tipo ansiolítico no labirinto em cruz elevado, semelhante ao produzido pela lesão eletrolítica de todo o septo.

Finalmente, com relação ao papel da acetilcolina na modulação da ansiedade, foi descrito um efeito de tipo ansiolítico no labirinto em cruz elevado após a injeção intraperitonial de um fármaco ativador de receptores neuronais colinérgicos nicotínicos em ratos e camundongos; esses efeitos permitem sugerir que os receptores nicotínicos centrais estão envolvidos na expressão do comportamento emocional (Brioni et al., 1993 e 1994). Em 1998, File e colaboradores relataram o efeito ansiogênico da injeção local no hipocampo do antagonista do receptor muscarínico M1 pirenzepina no teste de interação social, assim como do antagonista do receptor nicotínico mecamilamina. Esse antagonista muscarínico produziu efeito de tipo ansiogênico em uma segunda sessão do labirinto em cruz elevado. Os autores sugerem uma ação ansiolítica tônica para os receptores pós-sinápticos muscarínicos de tipo M1 no hipocampo, assim como para os receptores nicotínicos pré-sinápticos que reduzem a liberação de acetilcolina.

\section{E. O LABIRINTO EM CRUZ ELEVADO COMO MODELO EXPERIMENTAL DE COMPORTAMENTO EXPLORATÓRIO, ANSIEDADE E MEMÓRIA}

A maioria dos experimentos desenvolvidos para o estudo do papel das estruturas límbicas no armazenamento e recuperação de informação tem usado ratos treinados em tarefas que requerem o aprendizado de respostas complexas ou a privação alimentar, o que dificulta a interpretação dos resultados das lesões ou intervenções 
farmacológicas. Uma situação semelhante pode ser observada com alguns modelos animais criados para estudar a ansiedade (Treit, 1985, 1994). Esse fato tem sido parcialmente contornado com o uso do labirinto em cruz elevado, um modelo animal que demostrou ser muito eficiente na avaliação de uma grande parte dos fármacos ansiolíticos (Handley e Mithani, 1984; Pellow et al., 1985; File, 1993), no estudo dos mecanismos cerebrais que modulam a ansiedade (Pesold e Treit 1992, 1994, 1995, 1996; Menard e Treit, 1996a, 1996b), e mais recentemente, nos estudos sobre aprendizagem e memória (Itoh e al., 1991; Cunha et al., 1992; Imperato et al, 1994; Miyazaki et al., 1995a, b; Rodgers et al., 1996; Hlinak e Krejci, 1998).

Esse teste comportamental originou-se com os estudos sobre exploração e medo realizados por K.C. Montgomery na década do 50. Esse autor originalmente levantou a hipótese de que a estimulação provocada pela novidade (na forma de um ambiente desconhecido) produzia reações conflituosas de medo e curiosidade, comportamentalmente evidenciadas como tendências de esquiva e aproximação, respectivamente (Montgomery, 1955; Montgomery e Monkman, 1955). No labirinto em forma de $\mathrm{Y}$, utilizado originalmente por Montgomery, observava-se uma menor freqüência de entradas no braço aberto (sem paredes) em comparação com o braço fechado (cercado por paredes altas). Na versão atualmente utilizada do labirinto em cruz elevado (inicialmente proposta por Handley e Mithani, 1984, e validada comportamental, fisiológica e farmacologicamente por Pellow e colaboradores em 1985), o animal é exposto a um ambiente com duas áreas abertas e duas áreas fechadas, com áreas do mesmo tipo opostas entre si. Em sessões padronizadas de cinco minutos, a maioria dos animais exploram ativamente as quatro áreas do labirinto durante os primeiros minutos. Ao longo da sessão, os animais diminuem progressivamente sua atividade geral, principalmente o número de entradas nos braços 
abertos, passando cada vez mais tempo nos braços fechados. No total, entretanto, a observação do número médio de entradas e do tempo de permanência em cada tipo de braço nos cinco minutos de sessão (índices tradicionalmente utilizados para este modelo) mostra uma marcada preferência pela exploração dos braços fechados, evidenciada por um maior número de entradas e um maior tempo de permanência neles. Outros comportamentos além da movimentação exploratória do animal podem ser registrados (Cruz, et al. 1994), e atualmente esses índices são utilizados em vários estudos nos quais e utilizado o labirinto em cruz elevado como teste de ansiedade (Rodgers e Cole, 1994; Rodgers et al., 1997; Anseloni e Brandão, 1997).

Este transcurso temporal da atividade no labirinto indica, entre outras coisas, processos de armazenamento e recuperação da informação, referentes ao repertório de comportamentos exploratórios do rato. No entanto, essa característica não tem sido explorada e, até onde se sabe, existe um único trabalho no qual se avalia minuto a minuto a atividade de camundongos no labirinto em cruz elevado (Rodgers et al., 1996). Esse estudo inicial, detalhando as características do comportamento exploratório dos camundongos no labirinto em cruz elevado, apresenta a possibilidade de utilização desse modelo de maneira mais ampla, permitindo aproveitar ao máximo intervenções farmacológicas ou fisiológicas custosas ou de difícil execução. Adicionalmente, o fato de ser esse um teste que não requer treino, faz do labirinto um modelo ideal para se testar o curso temporal de lesões de diferentes tipos. Finalmente, por ser o labirinto em cruz elevado um teste baseado em tendências exploratórias naturais dos ratos, permite contornar problemas metodológicos observados em outros modelos usados no estudo da ansiedade e da memória, tais como a necessidade de privação alimentar e do uso de estímulos aversivos artificiais, que dificultam a interpretação de resultados (Treit, 1985, 1994). 


\section{F. IMUNOTOXINA IgG-192 SAPORIN}

O crescente interesse pelo estudo dos mecanismos colinérgicos centrais, principalmente por seu papel em processos de armazenamento e recuperação de informação e também pelo descobrimento da sua deterioração na doença de Alzheimer, levou ao desenvolvimento de neurotoxinas que seletivamente se ligam a receptores colinérgicos (Willey et al., 1991). Uma delas, a imunotoxina antineuronal IgG-192 saporin (daqui em diante referida como apenas saporin), liga o anticorpo monoclonal IgG-192, que reconhece a proteína 75 do fator de crescimento nervoso (presente), com a citotoxina saporin, proveniente do extrato vegetal da planta Saponaria officinalis, a qual inativa a função dos ribosomas celulares produzindo a morte da célula por apoptose (Torres et al., 1994; Walsh et al., 1996).

Essa imunotoxina está dirigida ao receptor P75 localizado nos terminais nervosos colinérgicos do neocortex e do hipocampo no prosencéfalo basal, não sendo encontrada nos grupos celulares colinérgicos localizados no tronco cerebral rostral (Willey et al., 1991). A injeção específica de esta toxina dentro do núcleo septal medial produz uma perdida seletiva de neurônios colinérgicos e de marcadores neuroquímicos da sínteses de acetilcolina (Waite et al., 1994).

Desde sua introdução em 1991 (Wiley et al., 1991), o efeito da lesão com esta toxina tem sido provado em diferentes testes comportamentais. Em 1994, Torres e colaboradores injetaram seletivamente saporin em diferentes núcleos do sistema prosencefálico medial, produzindo uma perda seletiva de neurônios colinérgicos nas áreas selecionadas (núcleo septal medial, banda diagonal de Broca e núcleo basal 
magnocelular). Entretanto, estas perdas, não refletiram nenhum déficit aparente na execução de uma tarefa de aprendizagem espacial (labirinto aquático de Morris). Resultados negativos similares foram descritos por Baxter e colaboradores (1995, 1996) utilizando o mesmo teste de aprendizagem espacial. Posteriormente (Wiley et al., 1995), foi relatado que a injeção de saporin no ventrículo lateral afetou a execução de uma tarefa de esquiva inibitória (step-down passive avoidance) assim como a recuperação de uma tarefa de memória de trabalho espacial (não pareamento demorado ao modelo), medida no labirinto radial de 8 braços (Walsh et al., 1996; Shen et al.,1996).

\section{O B J E T I V O S E H I P Ó T ES ES}

O presente estudo tem por finalidade avaliar os efeitos de uma lesão altamente seletiva do componente colinérgico do sistema septo-hipocampal, utilizando a imunotoxina IgG-192 saporin no comportamento de ratos no labirinto em cruz elevado utilizando um paradigma de teste e reteste. O objetivo do presente estudo fundamentase em duas hipóteses. De acordo com a primeira, a projeção colinérgica do septo para o hipocampo é indispensável para a modulação da atividade elétrica do mesmo e para as funções de armazenamento e/ou recuperação de informação. Se isso for verdade, a lesão seletiva dessa via produzirá comportamento exploratório contínuo ao longo das sessões, sem decréscimos devido à habituação. De acordo com a segunda hipótese, a projeção colinérgica do septo para o hipocampo é fundamental na modulação da atividade elétrica do mesmo, e essa via septo-hipocampal participaria das reações a ambientes novos, potencialmente perigosos. Se isso for verdade, a lesão seletiva dessa 
via diminuirá os índices comportamentais associados à ansiedade, principalmente em uma segunda exposição a um ambiente novo.

\section{MÉ T O D O}

Sujeitos. Nos testes comportamentais foram utilizados ratos Wistar machos pesando $213 \pm 0.69$ (média \pm E.P.M., com os pesos variando de 184 e 246 gramas), provenientes do Biotério Geral da Universidade de São Paulo, campus de Ribeirão Preto. Os ratos foram recebidos no biotério do nosso laboratório com pesos entre 150 e $160 \mathrm{~g}$. Todos os animais foram hospedados em gaiolas comunitárias com seis sujeitos cada uma, e temperatura controlada $\left(25-27^{\circ} \mathrm{C}\right)$ e um ciclo claro-escuro de 12 horas (luzes acesas às 7:00 h). Durante o período de permanência no laboratório os animais tinham livre acesso a água e comida.

Equipamento. Os testes comportamentais foram realizados em um labirinto em cruz elevado convencional, elevado $50 \mathrm{~cm}$ do solo, constituído por dois braços abertos (50 x $10 \mathrm{~cm}$, com bordas de acrílico transparente de $1 \mathrm{~cm}$ de altura) e dois braços fechados $(50 \times 10 \mathrm{~cm})$ com paredes de madeira de $40 \mathrm{~cm}$ de altura) unidos por um quadrado central de $10 \mathrm{~cm}$ de lado, de forma que braços iguais ficavam opostos entre si. Para a analise posterior da distância percorrida pelos animais, cada um dos braços foi dividido em cinco quadrados de $10 \mathrm{~cm}$ de lado na hora da análise do vídeo. O labirinto era colocado em uma sala iluminada por uma lâmpada incandescente de $60 \mathrm{~W}$, localizada a 1,75 m acima do quadrado central (Morato e Castrechini, 1989). Os equipamentos utilizados na lesão e na análise bioquímica serão descritos na seção correspondente. 
Cirurgia. Após um período de adaptação de 72 horas no biotério, os ratos foram anestesiados com pentobarbital sódico $(60 \mathrm{mg} / \mathrm{kg})$ por via intraperitonial. Após tricotomia, eram fixados em um aparelho estereotáxico (David Kopf), com a barra do incisor a 3mm abaixo da linha interaural. Em seguida foi feita a assepsia e a administração do anestésico local (cloridrato de lidocaína) subcutaneamente. A seguir, o crânio do animal era exposto e o periósteo removido com auxilio de um bisturi. Uma agulha odontológica era dirigida às seguintes coordenadas (com o bregma servindo como referência): $\mathrm{AP}=0,6 \mathrm{~mm} ; \mathrm{DV}=6,5 \mathrm{~mm} ; \mathrm{ML}=0,0 \mathrm{~mm}$ (Paxinos e Watson, 1982). Com uma perfuratriz (Dremel 395), foi feito um orifício para a introdução da agulha de microinjeção. Os animais lesados receberam a imunotoxina através de uma bomba de infusão. Os animais do grupo de lesão fictícia receberam apenas solução salina usando as mesmas coordenadas que as do grupo lesado. Finalmente um grupo de animais não recebeu nenhum tratamento antes de ser testado no labirinto em cruz elevado, e foi considerado como grupo controle.

Procedimento. Após um período de recuperação pós-cirúrgica de doze dias, os animais foram colocados individualmente no quadrado central do labirinto em cruz elevado, com o focinho voltado para um dos braços fechados, por um período de cinco minutos. Após este período, os animais eram levados de volta à sua gaiola, onde permaneciam por uma hora. Entre um animal e outro, o labirinto era cuidadosamente limpo com uma solução de álcool 10\%. Decorrido esse período de uma hora, os animais eram novamente colocados no labirinto por mais cinco minutos. Para cada uma dessas duas sessões, foram registrados o numero de entradas e o tempo de permanência em cada braço, a distância total percorrida, o número de entradas e o tempo gasto nas 
extremidades de cada braço bem como o numero e duração de levantar-se (rearing), esticar-se (stretching), mergulhar a cabeça (head deeping) e limpar-se (grooming). Uma entrada era registrada sempre que o animal entrava com ambas as patas traseiras em um braço. O mesmo critério foi usado para se considerar os quadrados atravessados, isto é, a frequiência só era contada quando o rato deixava completamente o quadrado anterior e colocava ambas as patas traseiras no quadrado seguinte. $\mathrm{O}$ comportamento de levantar-se era registrado sempre que os animais ficavam apoiados somente sobre as patas traseiras. O comportamento de esticar-se era registrado quando o animal espichava o corpo, freqüentemente com as patas traseiras paradas e com movimentos das dianteiras. O comportamento de mergulhar a cabeça era registrado toda vez que os animais abaixavam a cabeça em direção ao solo e os olhos ficavam abaixo do nível do piso do labirinto. O comportamento de limpar-se incluiu todas as respostas em que o animal esfregasse as patas dianteiras, traseiras, os dentes e/o língua pela cabeça, vibrissas, corpo e cauda. Os dados da primeira sessão foram também analisados minuto a minuto.

Drogas. A imunotoxina IgG-192 saporin (Chemicon International Inc., California, EUA) foi gentilmente fornecida por Thomas Walsh, da Universidade de Rutgers, Nova Jersey, EUA. Após atingir as estruturas alvo com a agulha, efetuou-se a infusão da imunotoxina $237,5 \mathrm{ng}$ em um volume de $0,5 \mu \mathrm{l}(475 \mathrm{ng} / \mu \mathrm{l})$ durante dois minutos. A velocidade da infusão $(0,25 \mu \mathrm{l} / \mathrm{min})$ foi controlada por uma bomba de infusão (Harvard Apparatus Modelo 55-2222) acoplada a uma seringa Hamilton de 10 $\mu$ l. A agulha de injeção permanecia no local por dois minutos após o termino da infusão, para impedir o refluxo. Logo após os animais receberam injeções com 120.000 unidades de 
penicilina $\mathrm{G}$ benzatina (Fontoura-Wyeth-Brasil) por via intramuscular, para evitar infecções.

Análise bioquímica. Trinta dias após a avaliação comportamental, os ratos foram sacrificados, e seus cérebros foram retirados. Posteriormente foram dissecados sobre placa fria o septo, o córtex pre-frontal e os hipocampos dos animais de todos os grupos. As amostras foram armazenadas em papel de alumínio a $-70{ }^{\circ} \mathrm{C}$, para analise posterior. A determinação da atividade da acetilcolinestease das diferentes regiões, foi feita utilizando-se o método de Ellman com as modificações introduzidas por Augustinsson (1978), de acordo com o procedimento que se segue. Os tecidos foram pesados individualmente e homogeneizados em metal vidro por 10 segundos a 18.000 revoluções por minuto em 1:200 (peso: volume) de tampão fosfato salino (PBS) 0,1 M, pH 7,3 com $1 \%$ de Triton X-100 a $4{ }^{\circ} \mathrm{C}$. O homogenado foi então centrifugado por 15 minutos a $10.000 \mathrm{~g}$ (centrifuga HIMAC-CR20B2).

A atividade da acetilcolinesterase foi determinada no sobrenadante imediatamente após a conclusão do ciclo de centrifugação. Para tanto, foram retiradas alíquotas de $150 \mu \mathrm{l}$ das amostras, às quais se acrescentou uma solução de 4-4dithiodipiridina (concentração final de 0,2 mM; SIGMA, St. Louis, MO, EUA) e o tampão de homogeneização PBS $(0,1 \mathrm{M}) \mathrm{m}$ até atingir um volume final de $1 \mathrm{ml} \mathrm{em}$ cubetas termostatizadas a $37{ }^{\circ} \mathrm{C}$. Três minutos após a incubação, adicionou-se acetiltiocolina $(1 \mathrm{mM})$ como substrato da acetilcolinesterase. Desta maneira, a atividade enzimática foi medida pela diferença de absorbância em 324 nm, utilizandose um espectrofotômetro VARIAN (modelo DMS 80). A medida da absorbância foi feita em triplicata para cada amostra de tecido, 12 e 3 minutos após a adição da 
acetiltiocolina. O dado utilizado na análise estatística foi a média dessas três medidas em cada minuto.

Analise estatística. Os dados comportamentais de cada sessão foram submetidos a uma análise de variância (ANOVA) seguida pelo teste $t$ de Bonferroni, para comparação entre médias de grupos e um grupo controle. A comparação do comportamento para cada grupo entre a primeira e a segunda sessões no labirinto, foram feitas com o teste $t$ de Student para amostras pareadas. Na análise minuto a minuto da primeira sessão, foi utilizada uma ANOVA para medidas repetidas, seguida pelo teste $t$ Bonferroni para comparações múltiplas com um nível de significância de 0,05. Adicionalmente compararam-se os dados dos três grupos experimentais em cada minuto para cada grupo experimental, usando para isto uma análise de variância (ANOVA) seguida pelo teste $t$ de Bonferroni para comparação com um grupo controle. Finalmente, os dados bioquímicos foram analisados por uma ANOVA comparando-se as médias de cada grupo em cada minuto, seguida pelo teste $t$ de Bonferroni para comparações com um controle.

\section{R E S U L T A D O S}

\section{$\underline{\text { 1. Análise Bioquímica }}$}

Atividade da acetilcolinesterase. A Figura 1 mostra a média dos níveis de absorbância de acetilcolinesterase para cada estrutura dos grupos controle, salina e saporin, em cada um dos três minutos da medida. A ANOVA mostrou uma diferença entre os 
valores de absorbância para o primeiro minuto no hipocampo $(\mathrm{F}[2,36]=167,706, \mathrm{P}<$ 0.001), córtex $(\mathrm{F}[2,31]=29,974, \mathrm{P}<0.001)$ e septo $(\mathrm{F}[2,32]=13,764, \mathrm{P}<0.001)$, sendo que, nas três áreas, o grupo de saporin apresentou uma absorbância menor que a do grupo controle (Bonferroni, $\mathrm{P}<0,05$ ).

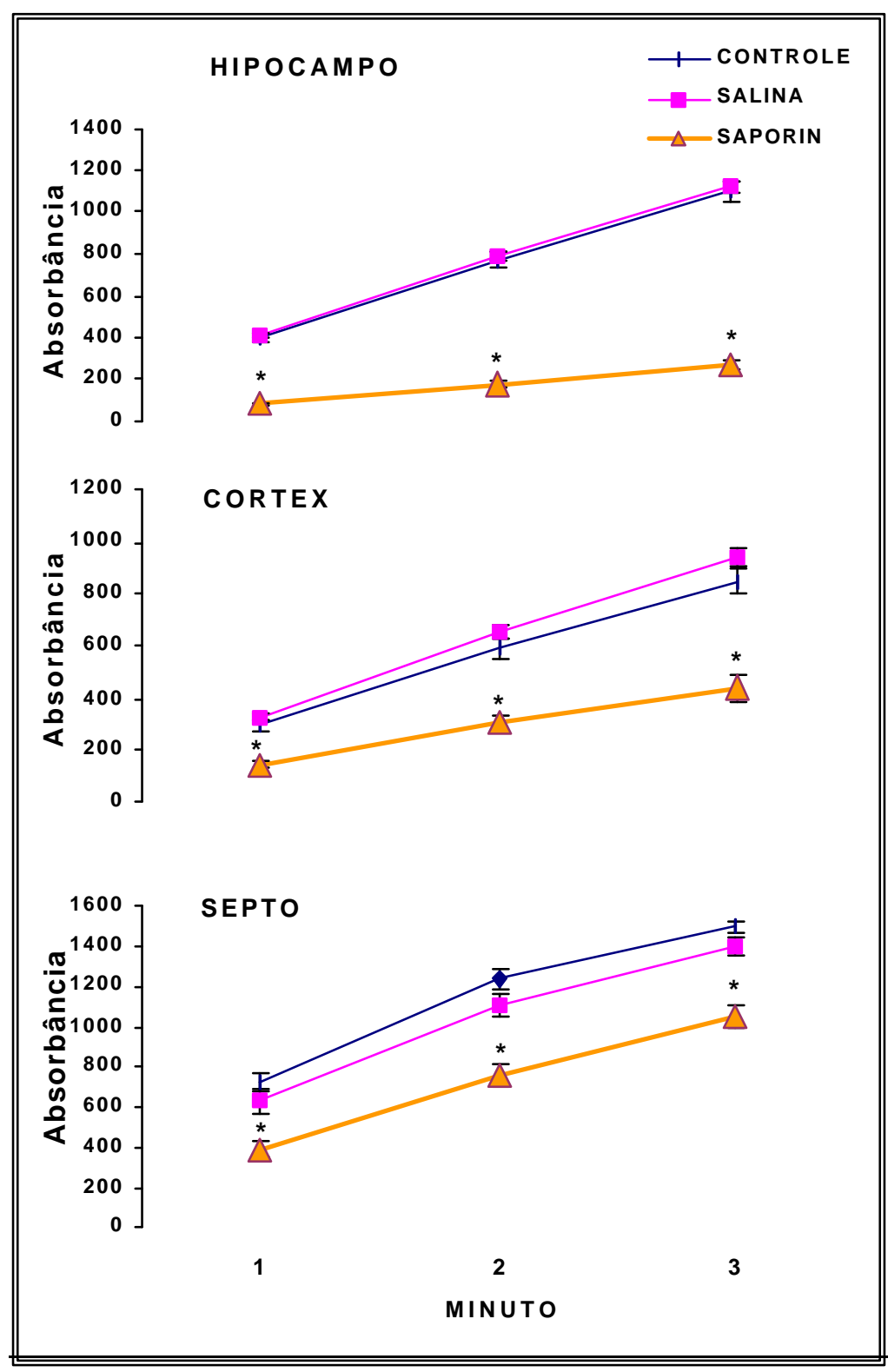

Figura 1: Níveis de absorbância da acetilcolinesterase para (a) hipocampo, (b) córtex e (c) septo durante os três minutos de leitura. Media $( \pm$ EPM) das três medições feitas para cada amostra. *, diferente do grupo controle e do grupo injetado com salina para cada minuto.

Mostrou também uma diferença entre os valores de absorbância para o segundo minuto no hipocampo $\left(\mathrm{F}_{[2,36]}=189,092, \mathrm{P}<0.001\right)$, córtex $\left(\mathrm{F}_{[2,31]}=30,461, \mathrm{P}<0.001\right)$ e septo $\left(F_{[2,32]}=21,419, \mathrm{P}<0.001\right)$, sendo que, nas três áreas, novamente, o grupo injetado com saporin apresentou uma absorbância menor que a do grupo controle 
(Bonferroni, $\mathrm{P}<0,05$ ). Para o terceiro minuto, a ANOVA, finalmente, mostrou uma diferença entre os valores de absorbância do homogenado do hipocampo $\left(\mathrm{F}_{[2,36]}=\right.$ 230,60, $\mathrm{P}<0.001)$, córtex $\left(\mathrm{F}_{[2,31]}=34,668, \mathrm{P}<0.001\right)$ e septo $\left(\mathrm{F}_{[2,32]}=23,660, \mathrm{P}<\right.$ 0.001), sendo que, nas três áreas, o grupo lesado mais uma vez apresentou uma absorbância menor que a do grupo controle (Bonferroni, $\mathrm{P}<0,05$ ).

\section{Análise Comportamental dos Totais de Respostas no Teste e Reteste}

Atividade Geral. A Figura 2 mostra as médias da distância total percorrida e a soma total de entradas nos braços abertos e fechados

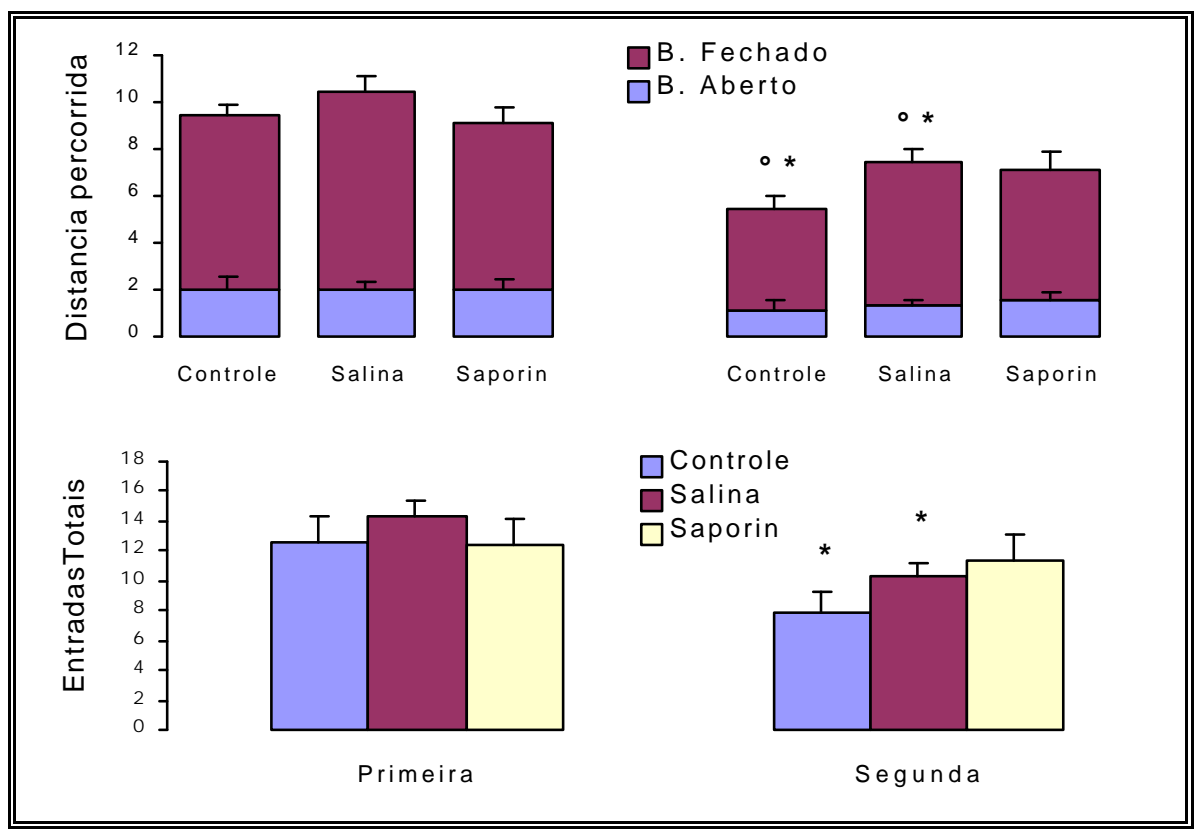

Figura 2 : (a) Média $( \pm$ EPM) da distancia percorrida nos braços abertos e fechados do labirinto para cada grupo nas duas sessões. *, diferente do braço fechado do mesmo grupo na primeira sessão. ${ }^{\circ}$, diferente da distancia total percorrida na primeira sessão. (b) Media $¥$ EPM) do número total de entradas nas duas sessões para cada grupo. *, diferente do total de entradas na primeira sessão.

Não se observou quaisquer diferenças significativas entre os três grupos quanto à distância total percorrida na primeira sessão $\left(\mathrm{F}_{[2,36]}=0,525, \mathrm{P}=0,596\right)$ nem na segunda $\left(\mathrm{F}_{[2,36]}=1,314, \mathrm{P}=0,281\right)$. Porém, o teste $t$ de Student para amostras pareadas mostrou que os grupos controle $\left(\mathrm{t}_{[22]}=3,027, \mathrm{P}=0,006\right)$ e salina $\left(\mathrm{t}_{[22]}=2,879, \mathrm{P}=\right.$ 0,009) percorreram uma distância significativamente menor na segunda sessão. 
Mostrou também que o grupo saporin não exibiu diferenças entre a primeira e segunda sessões $\left(\mathrm{t}_{[28]}=1,364 \mathrm{P}=0,183\right)$. A distância percorrida nos braços fechados também não foi diferente entre os três grupos na primeira $\left(\mathrm{F}_{[2,36]}=1,217, \mathrm{P}=0,308\right)$ nem na segunda sessões $\left(\mathrm{F}_{[2,36]}=1,741, \mathrm{P}=0,190\right)$. Porém, como na distância total, o teste $t$ de Student para amostras pareadas indicou que os grupos controle $\left(\mathrm{t}_{[22]}=4,223 \mathrm{P}<0,001\right)$ e salina $\left(\mathrm{t}_{[22]}=2,823 \mathrm{P}=0,010\right)$ percorreram uma distância significativamente menor na segunda sessão, indicando que a queda nos totais deveu-se à queda nesses braços, já que não ocorreram diferenças na distância percorrida nos braços abertos (ver adiante). Mostrou também que o grupo saporin não exibiu diferenças entre a primeira e segunda sessões $\left(\mathrm{t}_{[28]}=1,501 \mathrm{P}=0,145\right)$.

O número de entradas nos braços fechados (Figura 3) também não foi diferente entre os três grupos na primeira $(\mathrm{F}[2, .36=1,123, \mathrm{P}=0,337)$ nem na segunda sessões $\left(\mathrm{F}_{[2,36]}=1,453, \mathrm{P}=0,247\right)$. Porém, o teste $t$ de Student para amostras pareadas indicou que os grupos controle $\left(\mathrm{t}_{[22]}=2,307, \mathrm{P}=0,031\right)$ e salina $\left(\mathrm{t}_{[22]}=2,402, \mathrm{P}=0,025\right)$ entraram significativamente menos no braço fechado na segunda sessão. Mostrou também que o grupo saporin não exibiu diferenças entre a primeira e segunda sessões $\left(\mathrm{t}_{[28]}=0,476, \mathrm{P}=0,638\right) . \mathrm{O}$ tempo gasto nos braços fechados também não foi diferente entre os três grupos na primeira $\left(\mathrm{F}_{[2,36]}=0,341, \mathrm{P}=0,713\right)$ nem na segunda sessões $\left(\mathrm{F}_{[2,36]}=1.947, \mathrm{P}=0,157\right)$. O teste $t$ de Student para amostras pareadas indicou que os grupos controle $\left(\mathrm{t}_{[22]}=1,333, \mathrm{P}=0,195\right)$ salina $\left(\mathrm{t}_{[22]}=0,427, \mathrm{P}=0,673\right)$ e saporin $\left(\mathrm{t}_{[28]}\right.$ $=0,711, \mathrm{P}=0,483)$ não tiveram diferenças significativas no tempo gasto no braço fechado na segunda sessão. 


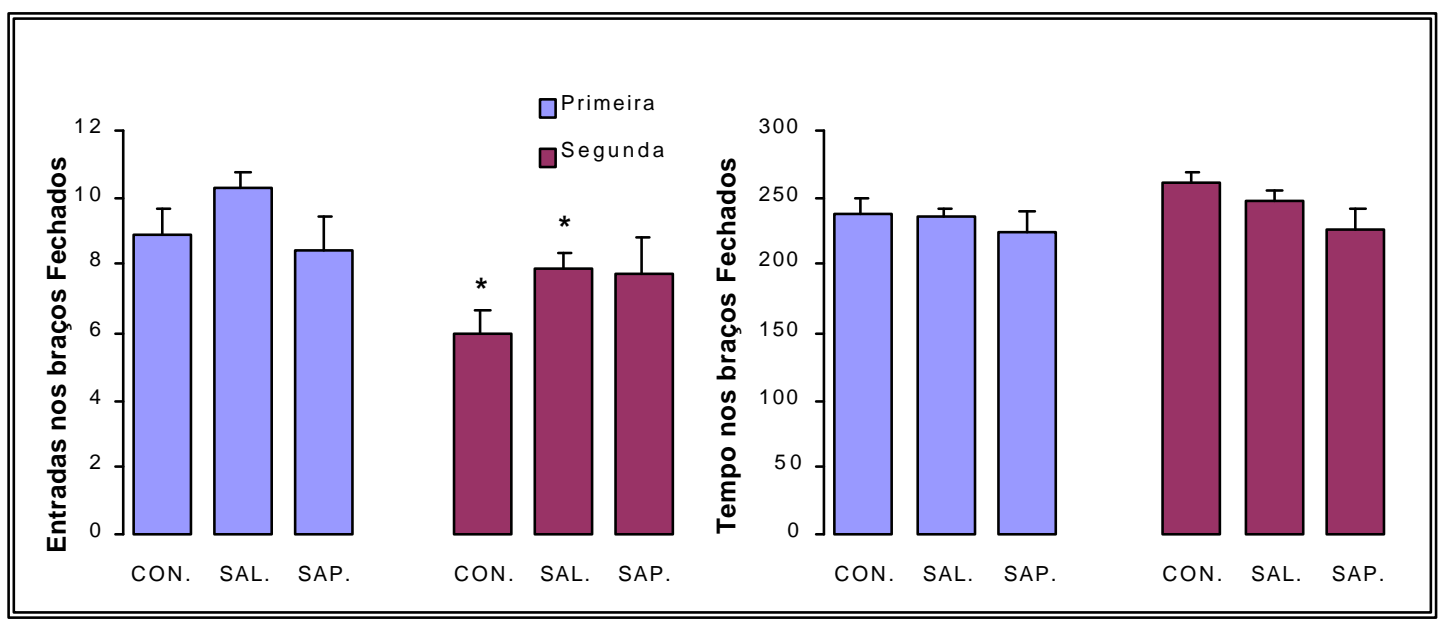

Figura 3: Entradas e tempo gasto nos braços fechados do labirinto (média \pm EPM) nas duas sessões para todos os grupos. *, diferente do mesmo grupo na primeira sessão.

A figura 4 mostra as médias das entradas e tempo de permanência total nas extremidades (discriminando o tipo de braço). Não se observou quaisquer diferenças significativas entre os três grupos quanto ao número total de entradas na primeira sessão $\left(\mathrm{F}_{[2,36]}=0,307, \mathrm{P}=0,738\right)$ nem na segunda $\left(\mathrm{F}_{[2,36]}=1,019, \mathrm{P}=0,371\right)$. Porém, o teste $t$ de Student para amostras pareadas mostrou que os grupos controle $\left(\mathrm{t}_{[22]}=3,680\right.$, $\mathrm{P}=0,001)$ e salina $\left(\mathrm{t}_{[22]}=2,853, \mathrm{P}=0,009\right)$ fizeram significativamente menos entradas na segunda sessão. Mostrou também que o grupo saporin não exibiu diferenças entre a primeira e segunda sessões $\left(\mathrm{t}_{228]}=2,007, \mathrm{P}=0,054\right)$. Tampouco observou-se quaisquer diferenças significativas entre os três grupos quanto ao tempo gasto nas extremidades totais na primeira sessão $\left(\mathrm{F}_{[2,36]}=0,00899, \mathrm{P}=0,991\right)$ nem na segunda $\left(\mathrm{F}_{[2,36]}=1,993\right.$, $\mathrm{P}=0,151)$. O teste $t$ de Student para amostras pareadas mostrou que os grupos controle $\left(\mathrm{t}_{[22]}=-0,664, \mathrm{P}=0,514\right)$, salina $\left(\mathrm{t}_{[22]}=-1,328, \mathrm{P}=0,198\right)$ e saporin $\left(\mathrm{t}_{[28]}=0,953, \mathrm{P}=\right.$ 0,349) não mostraram diferenças nos tempo gasto nas extremidades totais na segunda sessão. $\mathrm{O}$ número de entradas nas extremidades dos braços fechados também não foi 
diferente entre os três grupos na primeira $\left(\mathrm{F}_{[2,36]}=0,756, \mathrm{P}=0,477\right)$ nem na segunda sessões $\left(\mathrm{e}^{\mathrm{F}} \mathrm{F}_{2,36]}=0,953, \mathrm{P}=0,395\right)$. Porém, o teste $t$ de Student para amostras pareadas indicou que os grupos controle $\left(\mathrm{t}_{[22]}=4,306, \mathrm{p}=, 0,001\right)$ salina $\left(\mathrm{t}_{[22]}=2,753\right.$, $\mathrm{P}=0,012)$ e saporin $\left(\mathrm{t}_{[28]}=2,062, \mathrm{P}=0,049\right)$, entraram significativamente menos nas extremidades do braço fechado na segunda sessão, indicando que a queda nos totais deveu-se à queda nesses braços, já que não ocorreram diferenças nas entradas nas extremidades dos braços abertos (ver adiante).

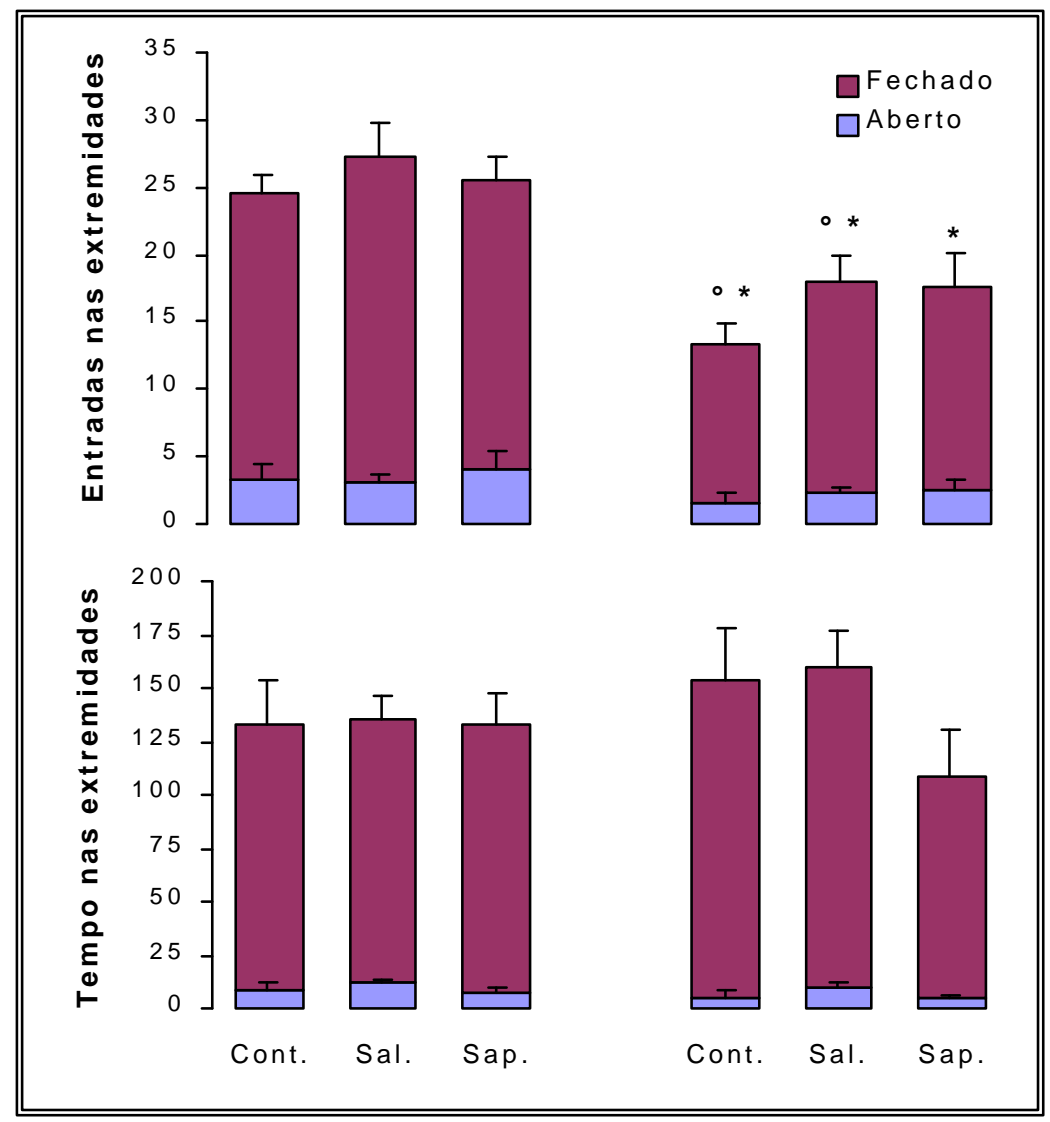

Figura 4: (a) Média $( \pm$ EPM) da frequiência de entradas nas extremidades dos braços para todos os grupos nas duas sessões. *, diferente da frequiência do braço fechado na primeira sessão. ०, diferente do total de entradas nas extremidades na primeira sessão. (b) Média ( \pm EPM) do tempo de permanência nas extremidades dos braços do labirinto nas duas sessões para todos os grupos.

Tampouco observou-se quaisquer diferenças significativas entre os três grupos quanto ao tempo gasto nas extremidades fechadas na primeira sessão $\left(\mathrm{F}_{[2,36]}=0,00323\right.$, $\mathrm{P}=0,997)$ nem na segunda $\left(\mathrm{F}_{[2,36]}=1,569, \mathrm{P}=0,222\right) . \mathrm{O}$ teste $t$ de Student para amostras pareadas mostrou que os grupos controle $\left(\mathrm{t}_{[22]}=-0,745, \mathrm{P}=0,464\right)$, salina 
$\left(\mathrm{t}_{[22]}=-1,325, \mathrm{P}=0,199\right)$ e saporin $\left(\mathrm{t}_{[28]}=0,806, \mathrm{P}=0,427\right)$ não mostraram diferenças nos tempo gasto nas extremidades fechadas na segunda sessão.

Comportamentos associados com a ansiedade. A distância percorrida nos braços abertos (Figura 2) não foi diferente entre os três grupos na primeira $\left(\mathrm{F}_{[2,36]}=0,003, \mathrm{P}=\right.$ $0,997)$ nem na segunda sessões $\left(\mathrm{F}_{[2,36]}=0,371, \mathrm{P}=0,693\right)$. O teste $t$ de Student para amostras pareadas indicou que os grupos controle $\left(\mathrm{t}_{[22]}=1,373, \mathrm{P}=0,183\right)$, salina $\left(\mathrm{t}_{[22]}\right.$ $=1,649, \mathrm{P}=0,113)$ e saporin $\left(\mathrm{t}_{[28]}=0,712, \mathrm{P}=0,483\right)$ não mostraram diferença na distância percorrida nos braços abertos na segunda sessão, indicando que a queda nos totais não deveu-se a esses braços.

O número de entradas nos braços abertos (Figura 5) não foi diferente entre os três grupos na primeira $\left(\mathrm{F}[2, .36=0,0234, \mathrm{P}=0,977)\right.$ nem na segunda sessões $\left(\mathrm{F}_{[2,36]}=\right.$ $1,248, \mathrm{P}=0,299)$. Porém, o teste $t$ de Student para amostras pareadas indicou que os grupos controle $\left(\mathrm{t}_{[22]}=1,798, \mathrm{P}=0,046\right)$ e salina $\left(\mathrm{t}_{[22]}=2,306, \mathrm{P}=0,031\right)$ entraram significativamente menos no braço aberto na segunda sessão.

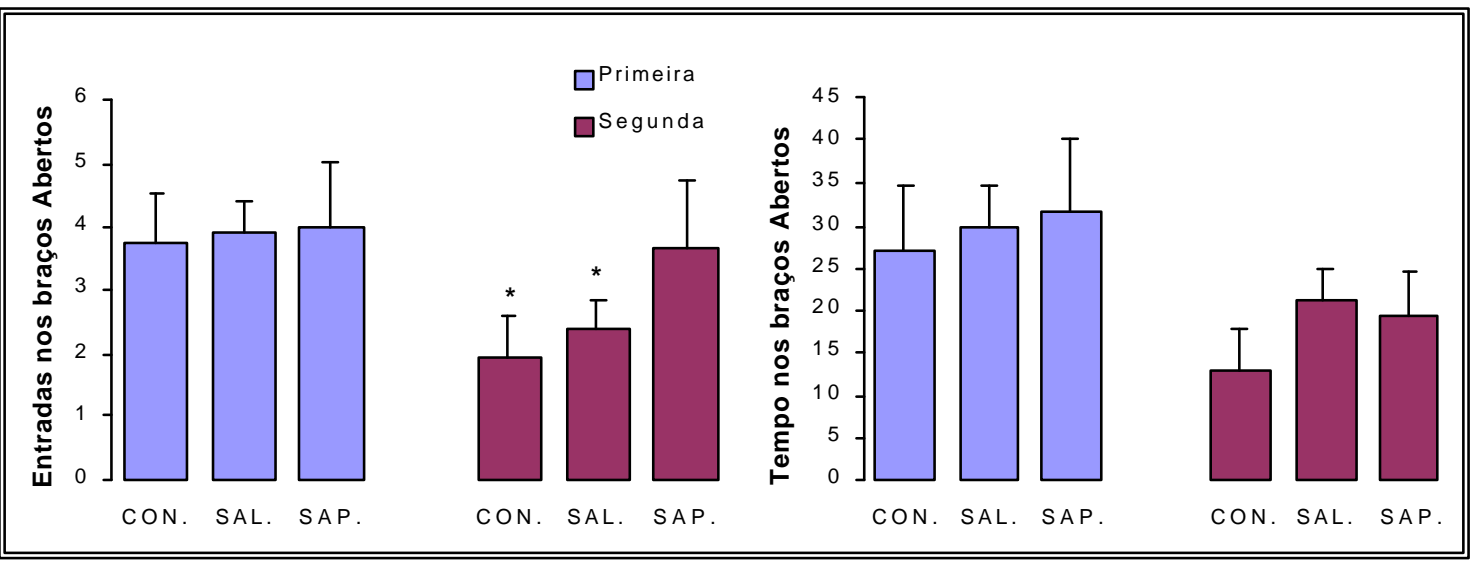

Figura 5: Entradas e tempo gasto nos braços abertos do labirinto (média \pm EPM) nas duas sessões para todos os grupos. ${ }^{*}$, diferente do mesmo grupo na primeira sessão.

entre a primeira e segunda sessões $\left(\mathrm{t}_{[28]}=0,227, \mathrm{P}=0,822\right)$. $\mathrm{O}$ tempo gasto nos braços 
abertos (Figura 5) também não foi diferente entre os três grupos na primeira $\left(F_{[2,36]}=\right.$ $0,107, \mathrm{P}=0,899)$ nem na segunda sessões $\left(\mathrm{F}_{[2,36]}=0.751, \mathrm{P}=0,479\right)$. O teste $t$ de Student para amostras pareadas indicou que os grupos controle $\left(\mathrm{t}_{[22]}=1,584, \mathrm{P}=\right.$ 0,127) salina $\left(\mathrm{t}_{[22]}=1,499, \mathrm{P}=0,148\right)$ e saporin $\left(\mathrm{t}_{[28]}=1,248, \mathrm{P}=0,222\right)$ não tiveram diferenças significativas no tempo gasto no braço aberto na segunda sessão.

O número de entradas nas extremidades dos braços abertos (Figura 4) não foi diferente entre os três grupos na primeira $\left(\mathrm{F}_{[2,36]}=0,283, \mathrm{P}=0,755\right)$ nem na segunda sessões $\left(\mathrm{F}_{[2,36]}=0,454, \mathrm{P}=0,639\right)$. $\mathrm{O}$ teste $t$ de Student para amostras pareadas indicou que os grupos controle $\left(\mathrm{t}_{[22]}=1.270, \mathrm{P}=0,217\right)$ salina $\left(\mathrm{t}_{[22]}=1.014, \mathrm{P}=0,322\right) \mathrm{e}$ saporin $\left(\mathrm{t}_{[28]}=1,050, \mathrm{P}=0,303\right)$, não mostraram diferenças significativas nas entradas nas extremidades abertas na segunda sessão, indicando que a queda nos totais não deveu-se à queda nesses braços. Não observou-se quaisquer diferenças significativas entre os três grupos quanto ao tempo gasto nas extremidades abertas na primeira sessão $\left(\mathrm{F}_{[2,36]}=0,822, \mathrm{P}=0,448\right)$ nem na segunda $\left(\mathrm{F}_{[2,36]}=1,561, \mathrm{P}=0,224\right) . \mathrm{O}$ teste $t$ de Student para amostras pareadas mostrou que os grupos controle $\left(\mathrm{t}_{[22]}=0,844, \mathrm{P}=\right.$ 0,408), salina $\left(\mathrm{t}_{[22]}=0,713, \mathrm{P}=0,483\right)$ e saporin $\left(\mathrm{t}_{[28]}=1,060, \mathrm{P}=0,298\right)$ não mostraram diferenças nos tempo gasto nas extremidades fechadas na segunda sessão

Tampouco observou-se quaisquer diferenças significativas entre os três grupos quanto ao tempo gasto no quadrado central do labirinto na primeira $\left(\mathrm{F}_{[2,36]}=0,571, \mathrm{P}=\right.$ $0,570)$ nem na segunda $\left(\mathrm{F}_{[2,36]}=2,766, \mathrm{P}=0,076\right)$ sessões.

Outros comportamentos: A Figura 6 mostra as médias dos comportamentos de esticarse, levantar-se, limpar-se e mergulhar a cabeça para os três grupos nas duas sessões.

A freqüência do comportamento de levantar-se foi diferente entre os três grupos na primeira sessão $\left(\mathrm{F}_{[2,36]}=4,352, \mathrm{P}=0,020\right)$ mas não na segunda $\left(\mathrm{F}_{[2,36]}=\right.$ 
0,694, $\mathrm{P}=0,506)$. O teste de Bonferroni mostrou diferença entre os grupos controle e saporin $(\mathrm{P}<0,005)$. O teste $t$ de Student para amostras pareadas indicou que o grupo controle $\left(\mathrm{t}_{[22]}=2,863, \mathrm{P}=0,009\right)$ diminuiu a freqüência de levantar-se na segunda sessão. Os grupos salina $\left(\mathrm{t}_{[22]}=2,026, \mathrm{P}=0,055\right)$ e saporin $\left(\mathrm{t}_{[28]}=1,123, \mathrm{P}=0,708\right)$, não mostraram diferenças significativas na frequiência de levantar-se na segunda sessão. Observou-se diferenças significativas entre os três grupos quanto ao tempo levantando-se na primeira sessão $\left(\mathrm{F}_{[2,36]}=3,389, \mathrm{P}=0,045\right)$ mais não na segunda $\left(\mathrm{F}_{[2,36]}=0,475, \mathrm{P}=0,626\right)$, porém $\mathrm{O}$ teste de Bonferroni não mostrou significância estatística para nenhum dos grupos. O teste $t$ de Student para amostras pareadas mostrou que os grupos controle $\left(\mathrm{t}_{[22]}=4,346, \mathrm{P}<0,001\right)$, salina $\left(\mathrm{t}_{[22]}=4,048, \mathrm{P}\right.$ $<0,001)$ e saporin $\left(\mathrm{t}_{[28]}=2,881, \mathrm{P}=0,008\right)$ mostraram uma queda significativa no tempo gasto no comportamento de levantar-se na segunda sessão.

A frequiência do comportamento de esticar-se foi diferente entre os três grupos na primeira sessão $\left(\mathrm{F}_{[2,36]}=5,461, \mathrm{P}=0,008\right)$ sendo diferentes os grupos salina e saporin $(\mathrm{P}<0,05)$, mas não na segunda sessão $\left(\mathrm{F}_{[2,36]}=0,587, \mathrm{P}=0,561\right)$. O teste $t$ de Student para amostras pareadas indicou que os grupos controle $\left(\mathrm{t}_{[22]}=2,240, \mathrm{P}=\right.$ 0,036), salina $\left(\mathrm{t}_{[22]}=3.382, \mathrm{P}=0,003\right)$ e saporin $\left(\mathrm{t}_{[28]}=2,101, \mathrm{P}=0,045\right)$, diminuíram a freqüência de esticar-se na segunda sessão. Observou-se diferenças significativas entre os três grupos quanto ao tempo de esticar-se na primeira sessão $\left(\mathrm{F}_{[2,36]}=7.792, \mathrm{P}\right.$ $=0,002) \mathrm{O}$ teste de Bonferroni mostrou diferencia entre os grupos controle e salina $(\mathrm{P}$ $<0,05)$ e salina e saporin $(\mathrm{P}<0,05)$. mais não na segunda sessão $\left(\mathrm{F}_{[2,36]}=1,989, \mathrm{P}=\right.$ 0,152). O teste $t$ de Student para amostras pareadas mostrou que os grupos controle $\left(\mathrm{t}_{[22]}=0,500, \mathrm{P}=0,622\right)$, salina $\left(\mathrm{t}_{[22]}=1,529, \mathrm{P}=0,141\right)$ e saporin $\left(\mathrm{t}_{[28]}=1,310, \mathrm{P}=\right.$ 0,201) não mostraram uma queda significativa no tempo gasto no comportamento de esticar-se na segunda sessão. 
A freqüência do comportamento de mergulhar a cabeça não foi diferente entre os três grupos nem na primeira $\left(\mathrm{F}_{[2,36]}=0,878, \mathrm{P}=0,424\right)$ nem na segunda sessões $\left(\mathrm{F}_{[2,36]}=0,138, \mathrm{P}=0,871\right) . \mathrm{O}$ teste $t$ de Student para amostras pareadas indicou que os grupos controle $\left(\mathrm{t}_{[22]}=2,712, \mathrm{P}=0,013\right)$ e salina $\left(\mathrm{t}_{[22]}=2,886, \mathrm{P}=0,077\right)$ diminuíram a frequiência de esticar-se na segunda sessão. Mostrou também que o grupo saporin não exibiu diferenças entre a primeira e segunda sessões $\left(\mathrm{t}_{[28]}=0,990, \mathrm{P}=0,331\right)$. Não observou-se diferenças significativas entre os três grupos quanto ao tempo de mergulhar a cabeça na primeira sessão $\left(\mathrm{F}_{[2,36]}=0,00904, \mathrm{P}=0,991\right)$ nem na segunda sessão $\left(\mathrm{F}_{[2,36]}=2,386, \mathrm{P}=0,106\right)$. $\mathrm{O}$ teste $t$ de Student para amostras pareadas mostrou que os grupos salina $\left(\mathrm{t}_{[22]}=3.555, \mathrm{P}=0,002\right)$ e saporin $\left(\mathrm{t}_{[28]}=2,377, \mathrm{P}=0,025\right)$ mostraram uma queda significativa no tempo gasto no comportamento de esticar-se na segunda sessão, enquanto o grupo controle não apresentou esta queda $\left(\mathrm{t}_{[22]}=1,521, \mathrm{P}\right.$ $=0,143)$.

Finalmente, a freqüência do comportamento de limpar-se não foi diferente entre os três grupos nem na primeira $\left(\mathrm{F}_{[2,36]}=0,608, \mathrm{P}=0,550\right)$ nem na segunda sessões $\left(\mathrm{F}_{[2,36]}=0,638, \mathrm{P}=0,534\right)$. O teste $t$ de Student para amostras pareadas indicou que os grupos controle $\left.t_{[22]}=-0,0500, \mathrm{P}=0,961\right)$, salina $\left(\mathrm{t}_{[22]}=-1,190, \mathrm{P}=0,247\right) \mathrm{e}$ saporin $\left(\mathrm{t}_{[28]}=0,659, \mathrm{P}=0,515\right)$ não foram diferentes na segunda sessão. 

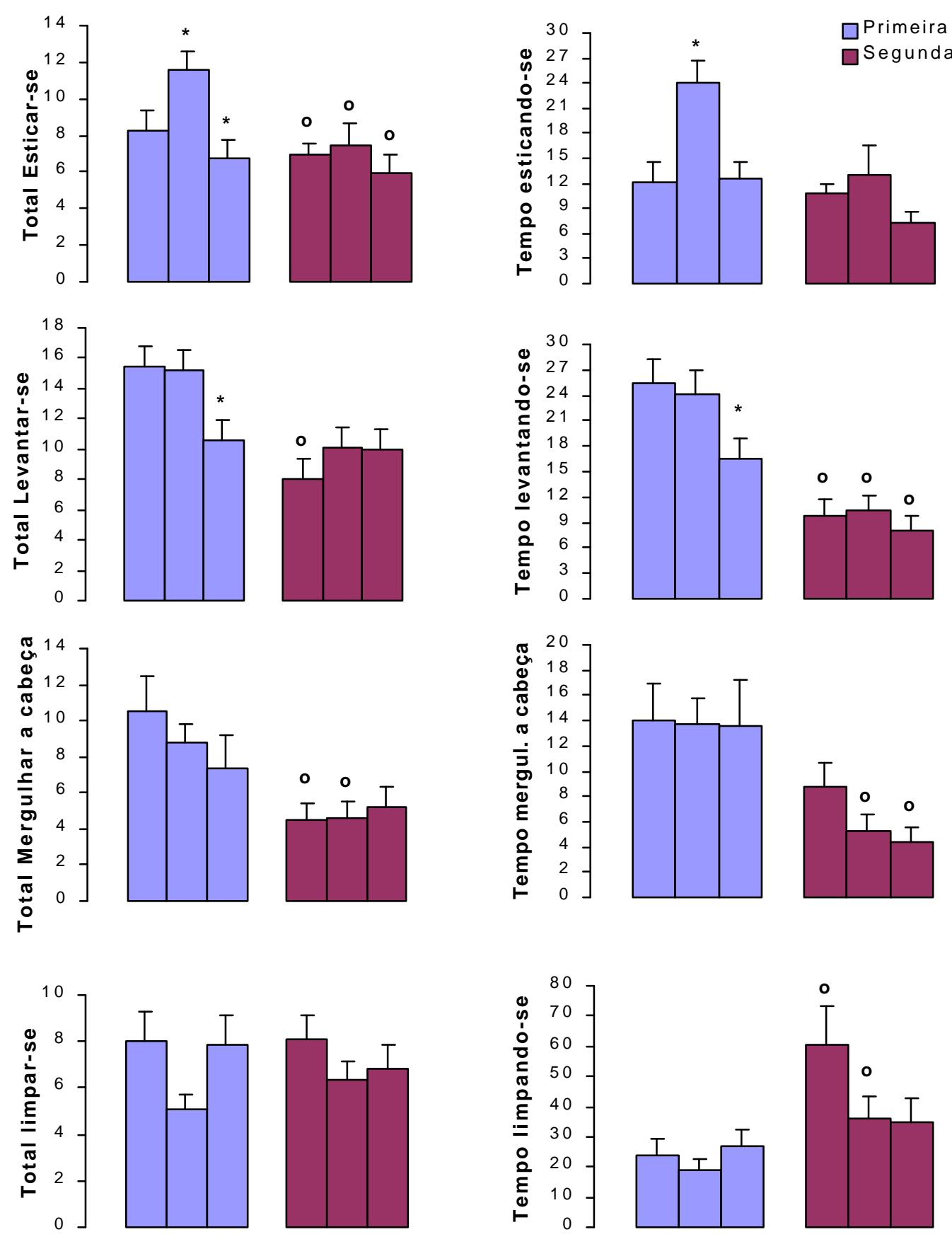

CN SL SP

CN SL SP

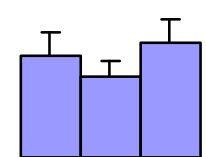

CN $\quad$ SL $\quad$ SP

CN SL SP

Figuras 6: Frequiências e tempos (média \pm EPM) para os comportamentos de esticar (a), levantar (b), mergulhar (c), e auto limpeza (d),para todos os grupos nas duas sessões. *, diferente do respectivo grupo controle na mesma sessão. ${ }^{\circ}$, diferente do mesmo grupo na primeira sessão.

Mostrou também que o grupo saporin não exibiu diferenças entre a primeira e segunda sessões $\left(\mathrm{t}_{[28]}=0,990, \mathrm{P}=0,331\right)$. Não observou-se diferenças significativas 
entre os três grupos quanto ao tempo de limpar-se na primeira sessão $\left(\mathrm{F}_{[2,36]}=0,956, \mathrm{P}\right.$ $=0,394)$ nem na segunda sessão $\left(\mathrm{F}_{[2,36]}=0,813, \mathrm{P}=0,452\right)$. O teste $t$ de Student para amostras pareadas mostrou que os grupos controle $\left(\mathrm{t}_{22]}=-2,273, \mathrm{P}=0,014\right)$ e salina $\left(\mathrm{t}_{[22]}=-2,130, \mathrm{P}=0,045\right)$ mostraram uma queda significativa no tempo gasto no comportamento de limpar-se na segunda sessão, enquanto o grupo lesado não apresentou esta queda $\left(\mathrm{t}_{[28]}=-0,834, \mathrm{P}=0,411\right)$.

\section{Análise Comportamental da Primeira Sessão Minuto a Minuto}

Atividade Geral: A ANOVA revelou que, a distância total percorrida pelos animais do grupo controle foi diferente ao longo dos cinco minutos da primeira sessão $\left(\mathrm{F}_{[4,44]}=\right.$ 23,511, $\mathrm{P}<0,001$ ) (Figura 7). O teste de Bonferroni revelou que os ratos percorreram una distância menor nos minutos $2,3,4$ e 5 do que a percorrida no minuto 1 . Os animais do grupo salina também mostraram diferenças significativas no numero de cruzamentos totais ao longo dos cinco minutos da sessão $\left(\mathrm{F}_{[4,44]}=9,861, \mathrm{P}<0,001\right)$, sendo menores as distâncias percorridas nos minutos 2, 3, 4 e 5 do que a distância percorrida no minuto 1 segundo o teste de Bonferroni. Ao contrario da queda observada na distância total percorrida nos animais dos grupos controle e salina, os animais do grupo lesado não mostraram diferenças significativas ao longo da sessão $\left(\mathrm{F}_{[4,56]}=6,734, \mathrm{P}=0,486\right)$. A comparação da distância percorrida pelos animais no primeiro minuto foi diferente $\left(\mathrm{F}_{[2,36]}=6,734, \mathrm{P}=0,003\right)$, sendo que os ratos do grupo lesado percorreram una distância menor, enquanto os do grupo salina percorreram una distância semelhante à do grupo controle (teste de Bonferroni). A distância percorrida nos braços fechados para o grupo controle foi diferente ao longo da primeira sessão $\left(\mathrm{F}_{[4,44]}=24,743, \mathrm{P}<0,001\right)$, sendo que os ratos percorreram uma distância menor nos 
braços fechados nos minutos $2,3,4$ e 5 em comparação à percorrida no minuto 1 (Bonferroni, $\mathrm{P}<0,05)$. Os mesmos resultados foram observados para o grupo injetado com salina $\left(\mathrm{F}_{[4,44]}=6,033, \mathrm{P}<0,001\right)$, para o qual a distância percorrida nos braços fechados nos minutos 3, 4 e 5 foi menor do que a percorrida no minuto 1 (Bonferroni, $\mathrm{P}<0,05)$. Ao contrário, os animais do grupo lesado com saporin não apresentaram diferenças na distância percorrida nos braços fechados ao longo da primeira sessão $\left(\mathrm{F}_{[4,56]}=0,233, \mathrm{P}=0,919\right)$. A comparação da distância percorrida pelos animais no primeiro minuto foi diferente $\left(\mathrm{F}_{[2,36]}=14,041, \mathrm{P}<0,001\right)$, sendo que os ratos do grupo lesado com saporin (Bonferroni, $\mathrm{P}<0,05)$ percorreram um distância menor, enquanto os do grupo salina percorreram uma distância semelhante à do grupo controle (Bonferroni, $\mathrm{P}<0,05)$.

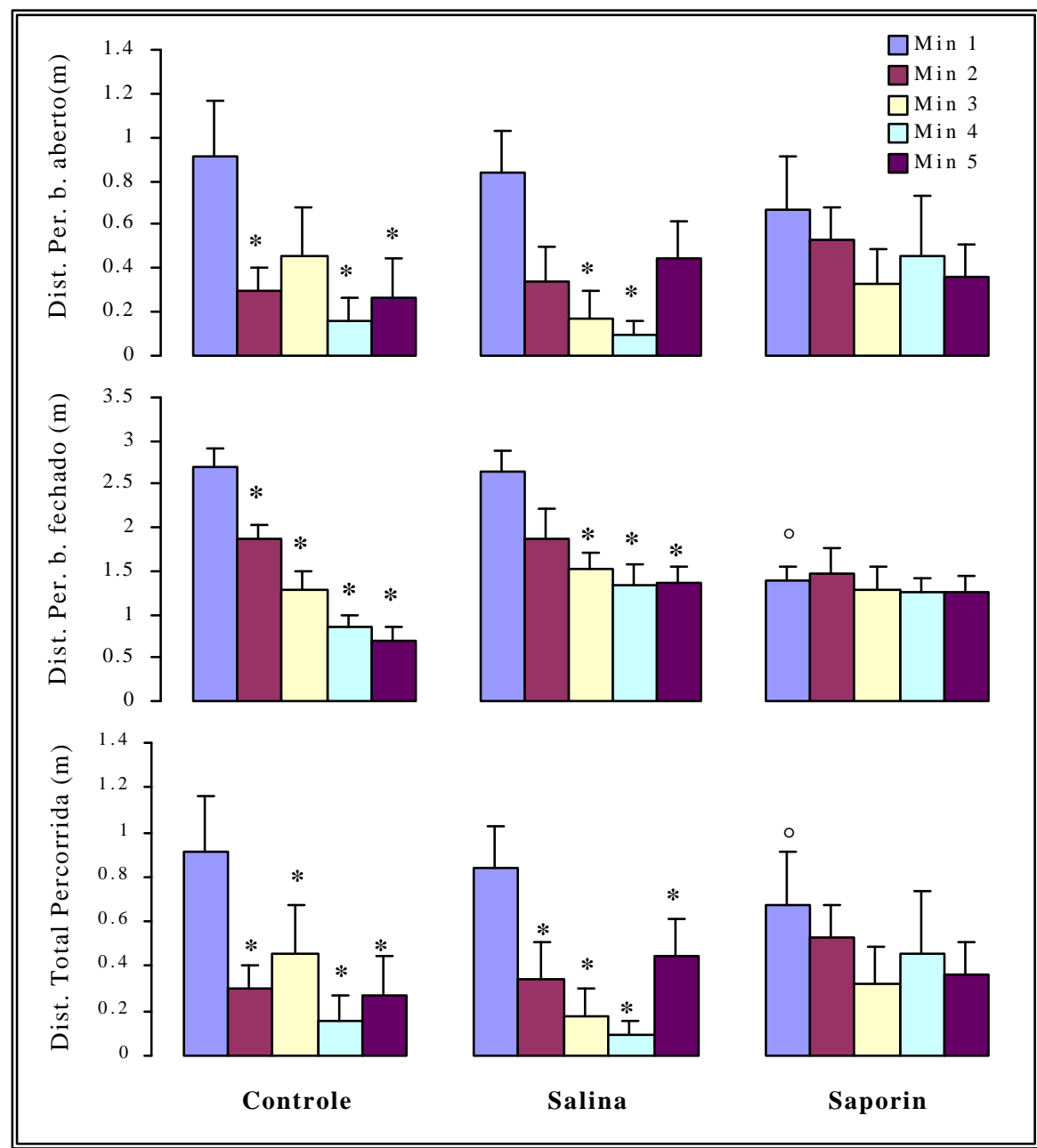

Figuras 7: Médias $( \pm$ EPM $) \quad$ da distancia percorrida nos braços abertos (a), fechados (b) $\epsilon$ distancia total (c) nos cinco minutos da primeira sessão para todos os grupos. *, diferente do primeiro minuto do mesmo grupo. ${ }^{\circ}$, diferente do primeiro minuto do grupo controle. 
As entradas totais nos braços do labirinto foram diferentes ao longo da primeira sessão para o grupo controle $\left(\mathrm{F}_{[4,44]}=20,940, \mathrm{P}<0,001\right)$, sendo que os animais fizeram um menor número de entradas nos minutos $2,3,4$ e 5 que no minuto 1 (teste de Bonferroni). Os animais do grupo salina, também apresentaram diferenças na freqüência total de entradas ao longo da primeira sessão $\left(\mathrm{F}_{[4,44]}=7,186, \mathrm{P}<0,001\right)$, observando-se uma queda no numero de entradas nos minutos 3,4 e 5 quando comparados com o minuto 1 segundo o teste de Bonferroni. O grupo de animais lesados não apresentou essa diferença na frequiência total de entradas ao longo da primeira sessão $\left(\mathrm{F}_{[4,56]}=1,779, \mathrm{P}=0,146\right)$. A comparação do número total de entradas nos braços do labirinto durante o primeiro minuto da primeira sessão mostrou diferenças para os três grupos $\left(\mathrm{F}_{[2,36]}=3,680, \mathrm{P}=0,035\right)$, sendo que os animais do grupo lesado fizeram um número menor de entradas, enquanto os animais do grupo salina fizeram um número semelhante de entradas que o grupo controle (teste de Bonferroni).

As entradas nos braços fechados foram diferentes para o grupo controle ao longo da primeira sessão $\left(\mathrm{F}_{[4,44]}=14,571, \mathrm{P}<0,001\right)$, sendo menor o número de entradas nos minutos $2,3,4$ e 5 quando comparados com o minuto 1 (teste de Bonferroni). O grupo salina também foi diferente em términos de entradas aos braços fechados do labirinto $\left(\mathrm{F}_{[4,44]}=3,627, \mathrm{P}=0,012\right)$, observando-se uma queda nos minutos 3, 4 e 5 quando comparados com o minuto 1 (teste $t$ de Bonferroni). O grupo lesado não apresentou diferença na freqüência de entradas nos braços fechados ao longo da sessão $\left(\mathrm{F}_{[4,56]}=0,662, \mathrm{P}=0,621\right)$. A comparação das entradas no braço fechado durante o primeiro minuto da primeira sessão mostrou diferenças para os três grupos $\left(\mathrm{F}_{[2,36]}=8.920, \mathrm{P}<0,001\right)$, sendo que os animais do grupo lesado fizeram menos entradas nos braços fechados, enquanto os animais do grupo salina não 


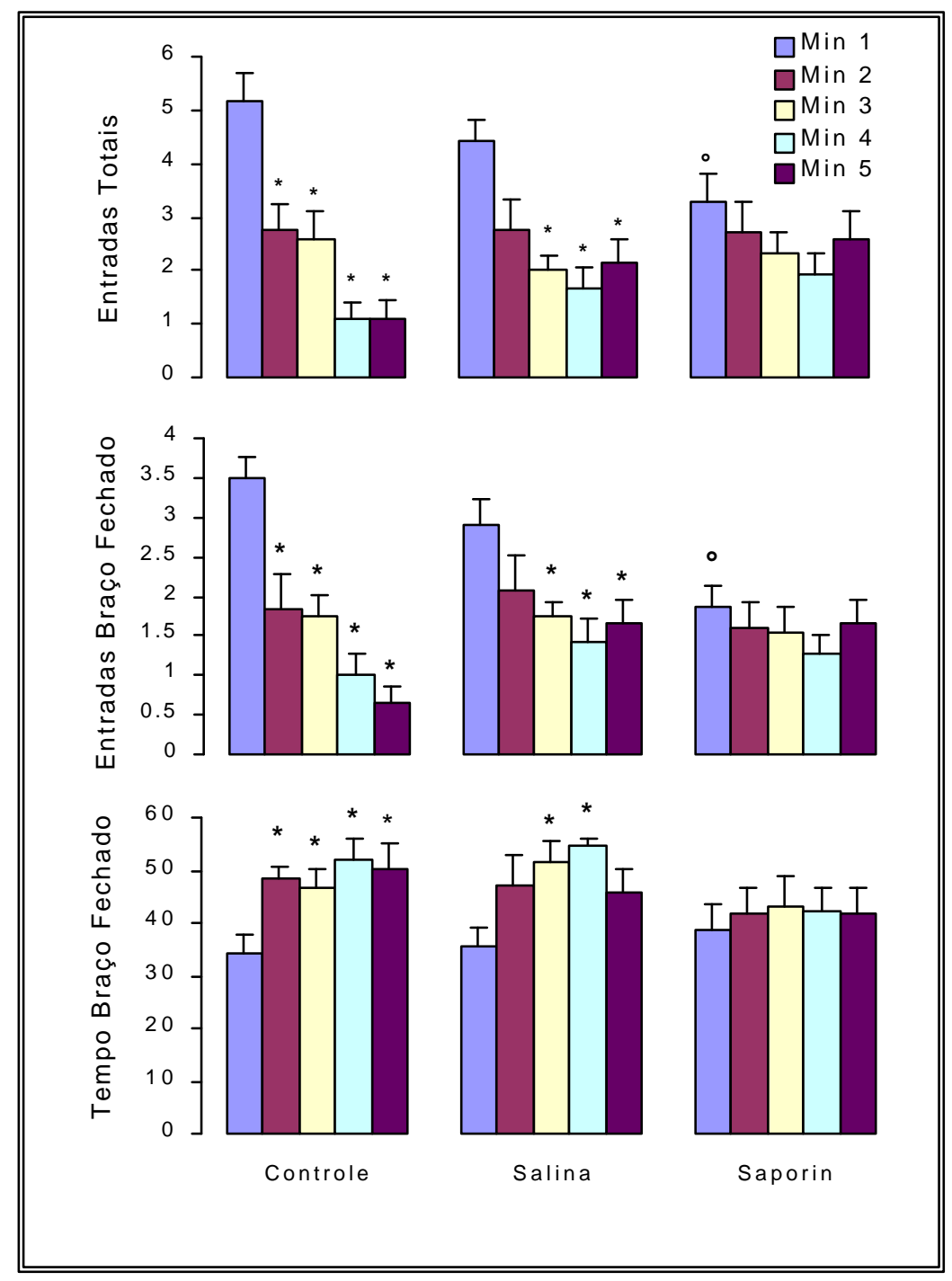

Figuras 8: Entradas totais, nos braços entradas nos braços fechados. (média \pm EPM) nos cinco minutos da primeira sessão do labirinto para todos os grupos *, diferente do primeiro minuto do mesmo grupo. ${ }^{\circ}$, diferente do primeiro minuto do grupo controle.

mostraram-se diferentes do grupo controle (teste de Bonferroni). O tempo de permanência no braço fechado para os animais do grupo controle foi diferente ao longo da primeira sessão $\left(\mathrm{F}_{[4,44]}=5.685, \mathrm{P}<0,001\right)$, sendo maior o tempo gasto nos minutos 2, 3, 4 e 5 quando comparado com o minuto 1 (teste de Bonferroni). Os animais do grupo salina também foram diferentes em termos do tempo gasto nos braços fechados $\left(\mathrm{F}_{[4,44]}=3.443, \mathrm{P}=0,016\right)$, observando-se um incremento no tempo gasto no braço fechado nos minutos 3 e 4 quando comparados com o minuto 1 (teste de Bonferroni). Os animais do grupo lesado não apresentaram diferenças no tempo de permanência nos braços fechados ao longo da primeira sessão $\left(\mathrm{F}_{[4,56]}=0,902, \mathrm{P}=\right.$ 
0,469). A comparação do tempo de permanência nos braços fechados durante o primeiro minuto da primeira sessão não foi diferente para os três grupos $\left(\mathrm{F}_{[2,36]}=\right.$ $0,281, \mathrm{P}=0,756)$ (Figura 8).

Comportamentos associados com a ansiedade: A ANOVA revelou que a distância percorrida nos braços abertos variou ao longo dos cinco minutos da primeira sessão para os animais do grupo controle $\left(\mathrm{F}_{[4,44]}=3,392, \mathrm{P}=0,017\right)$ e o teste $t$ de Bonferroni mostrou que os ratos percorreram uma distância menor nos minutos 2, 4 e 5 do que no minuto 1 (Bonferroni, $\mathrm{P}<0,05$ ) (Figura 7). O grupo salina também mostrou diferenças na distância percorrida nos braços abertos ao longo da primeira sessão $\left(\mathrm{F}_{[4,44]}=3,793\right.$, $\mathrm{P}=0,010)$ e o teste $t$ de Bonferroni mostrou que os ratos deste grupo percorreram uma distância menor nos minutos 3 e 4 do que no minuto 1 . O grupo lesado não mostrou quaisquer diferenças na distância percorrida nos braços abertos ao longo dos cinco minutos da primeira sessão $\left(\mathrm{F}_{[4,56]}=0,628, \mathrm{P}=0,644\right)$. Durante o primeiro minuto todos os três grupos percorreram uma distância estatisticamente semelhante $\left(\mathrm{F}_{[2,36]}=\right.$ $0,314, \mathrm{P}=0,732)$.

O grupo controle apresentou uma queda significativa nas entradas ao braço aberto do labirinto ao longo da primeira sessão $\left(\mathrm{F}_{[4,44]}=5.089, \mathrm{P}=0,002\right)$. O teste $t$ de Bonferroni mostrou uma queda nas entradas nos braços do labirinto nos minutos 4 e 5 quando comparados com o minuto 1. O grupo salina comportou-se de modo semelhante, com uma queda significativa na freqüência de entradas ao braço aberto $\left(\mathrm{F}_{[4,44]}=4,226, \mathrm{P}=0,006\right)$ e diminuição no número de entradas nos braços abertos nos minutos 3, 4 e 5 quando comparados com o minuto 1 . O grupo lesado não mostrou diferenças na freqüência de entradas nos braços abertos ao longo da sessão $\left(\mathrm{F}_{[4,56]}=\right.$ 0,902, $\mathrm{P}=0,469)$. A comparação no numero de entradas nos baços abertos durante o 
primeiro minuto da primeira sessão não mostrou diferenças entre os três grupos $\left(\mathrm{F}_{[2,36]}\right.$ $=0,132, \mathrm{P}=0,877)$. O tempo gasto nos braços abertos para o grupo controle mostrouse diferente ao longo da primeira sessão $\left(\mathrm{F}_{[4,44]}=3,086, \mathrm{P}=0,025\right)$, sendo que foi menor nos minutos 4 e 5 quando comparado com o minuto 1(teste de Bonferroni). O grupo salina também mostrou diferenças no tempo gasto nos braços abertos ao longo da primeira sessão $\left(\mathrm{F}_{[4,44]}=4,137, \mathrm{P}=0,006\right)$, observando-se queda no tempo gasto nos minutos 3 e 4 quando comparados com o minuto 1, segundo o teste de Bonferroni.

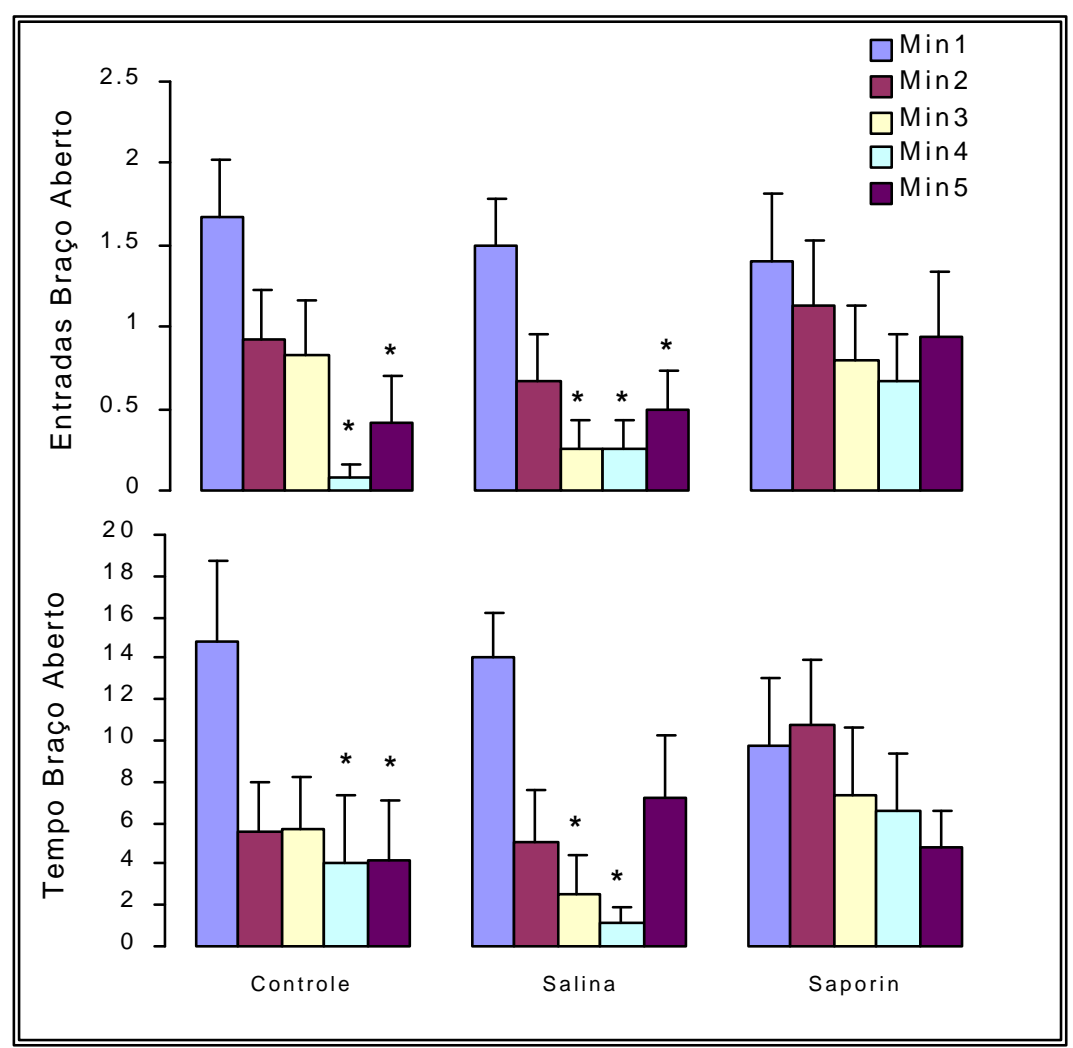

Figuras 9: Entradas (média \pm EPM) e tempo gasto nos braços fechados nos cinco minutos da primeira sessão do labirinto para todos os grupos. *, diferente do primeiro minuto do mesmo grupo. ${ }^{\circ}$, diferente do primeiro minuto do grupo controle.

O grupo lesado com saporin não mostrou diferencia no tempo nos braços abertos durante a primeira sessão $\left(\mathrm{F}_{[4,56]}=1,131, \mathrm{P}=0,351\right)$. A comparação no tempo de permanência nos braços abertos durante o primeiro minuto não mostrou diferença entre os grupos $\left(\mathrm{F}_{[2,36]}=0,652, \mathrm{P}=0,527\right)$. Finalmente, o tempo de permanência no quadrado central do labirinto não foi diferente para os animais do grupo controle ao 
longo da sessão $\left(\mathrm{F}_{[4,44]}=1,942, \mathrm{P}=0,120\right)$, enquanto foi observada uma diferença para o grupo injetado com salina $\left(\mathrm{F}_{[4,44]}=3.086, \mathrm{P}=0,025\right)$, sendo menor somente o minuto 2 do minuto 1 (teste de Bonferroni). Os animais do grupo lesado não apresentaram diferenças no tempo de permanência no centro ao longo da primeira sessão $\left(\mathrm{F}_{[4,56]}=\right.$ $1,251, \mathrm{P}=0,300)$. A comparação do tempo gasto no centro durante o primeiro minuto da primeira sessão não foi diferente para os três grupos $\left(\mathrm{F}_{[2,36]}=0,0178, \mathrm{P}=0,982\right)$. (Figura 9).

Outros comportamentos: A freqüência do comportamento de levantar foi significativamente diferente para os animais do grupo controle $\left(\mathrm{F}_{[4,44]}=3,550, \mathrm{P}=\right.$ 0,014), sendo diferente somente o minuto 5 quando comparado com o minuto 1 segundo o teste de Bonferroni. O número de levantamentos ao longo da primeira sessão não foi diferente para os animais do grupo salina $\left(\mathrm{F}_{[4,44]}=0,881, \mathrm{P}=0,483\right)$, nem para os animais do grupo saporin $\left(\mathrm{F}_{[4,56]}=0,981, \mathrm{P}=0,425\right)$. A freqüência de levantar-se durante o primeiro minuto da primeira sessão não foi diferente para nenhum dos grupos $\left(\mathrm{F}_{[2,36]}=2,589, \mathrm{P}=0,089\right)$. $\mathrm{O}$ tempo gasto no comportamento não foi diferente para os grupos controle $\left(\mathrm{F}_{[4,44]}=1,310, \mathrm{P}=0,281\right)$, salina $\left(\mathrm{F}_{[4,44]}=0,680\right.$, $\mathrm{P}=0,610)$, ou saporin $\left(\mathrm{F}_{[4,56]}=1,457, \mathrm{P}=0,228\right)$. O tempo de levantamentos no primeiro minuto da primeira sessão não foi diferente para nenhum dos três grupos testados $\left(\mathrm{F}_{[2,36]}=2,589, \mathrm{P}=0,089\right.$ e $\left.\mathrm{F}_{[2,36]}=0,199, \mathrm{P}=0,821\right)$.

A frequiência do comportamento de esticar foi diferente para o grupo controle ao longo da primeira sessão $\left(\mathrm{F}_{[4,44]}=2,644, \mathrm{P}=0,046\right)$, observando-se uma queda significativa no minuto 5 quando comparado com o minuto 1 (teste de Bonferroni). A freqüência de esticar-se no grupo salina não foi diferente ao longo da primeira sessão $\left(\mathrm{F}_{[4,44]}=2,128, \mathrm{P}=0,093\right)$ enquanto nos animais do grupo saporin observaram-se 
diferenças ao longo da primeira sessão $\left(\mathrm{F}_{[4,56]}=3,604, \mathrm{P}=0,011\right)$, sendo menor a freqüência de esticar no minuto 5 quando comparado com o minuto 1 (teste de Bonferroni). A analise da freqüência de esticar-se no primeiro minuto da primeira sessão não foi diferente para nenhum dos grupos $\left(\mathrm{F}_{[2,36]}=0,940, \mathrm{P}=0,400\right)$ Os tempos para esse comportamento não foram diferentes para o grupo controle $\left(\mathrm{F}_{[4,44]}=1,552, \mathrm{P}\right.$ $=0,204)$, salina $\left(\mathrm{F}_{[4,44]}=1,193, \mathrm{P}=0,327\right)$ ou saporin $\left(\mathrm{F}_{[4,56]}=1,131, \mathrm{P}=0,351\right) . \mathrm{O}$ tempo de esticar durante o primeiro minuto da primeira sessão não foi diferente para nenhum dos grupos $\left(\mathrm{F}_{[2,36]}=1,571, \mathrm{P}=0,222\right)($ Figura 10).

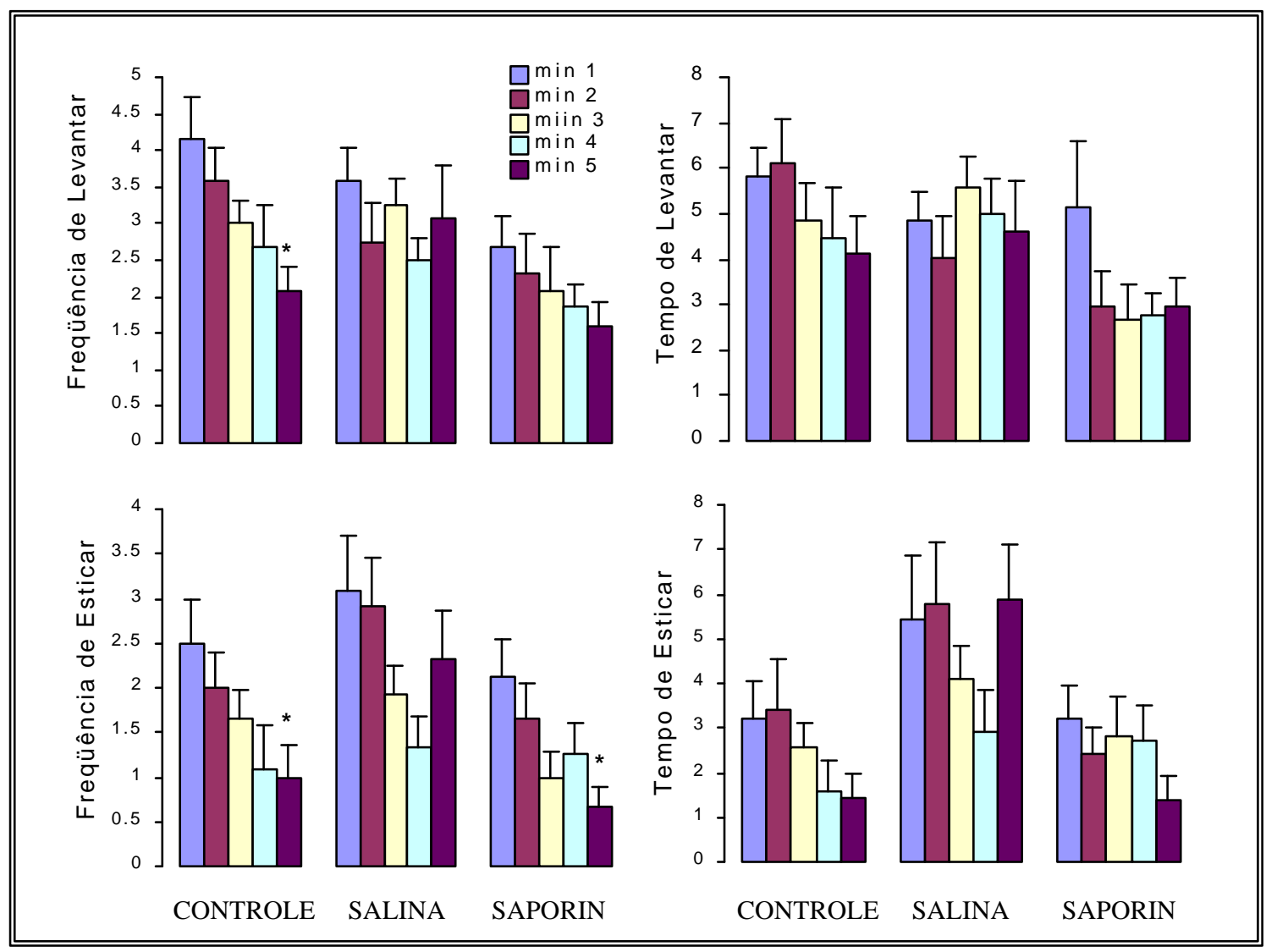

Figura 10: Frequiências e tempos (média \pm EPM) durante os cinco minutos para os comportamentos de levantar e esticar na primeira sessão do labirinto para todos os grupos. ${ }^{*}$, diferente do primeiro minuto do mesmo grupo.

A frequiência do comportamento de mergulhar a cabeça para os animais do grupo controle foi diferente ao longo da primeira sessão $\left(\mathrm{F}_{[4,44]}=4,437, \mathrm{P}=0,004\right)$, 
sendo menor a freqüência nos dos minutos 4 e 5 quando comparados com o minuto 1(teste de Bonferroni). A frequiência do comportamento de mergulhar a cabeça para os animais injetados com salina também foi diferente ao longo da sessão $\left(\mathrm{F}_{[4,44]}=5,714\right.$, $\mathrm{P}=0,001$ ), sendo menores as freqüências nos minutos 3,4 e 5 quando comparadas com o minuto 1 (teste de Bonferroni). O mesmo comportamento não foi diferente para os animais do grupo lesado ao longo da primeira sessão $\left(\mathrm{F}_{[4,56]}=1,963, \mathrm{P}=0,117\right)$. A comparação do primeiro minuto da primeira sessão não foi diferente para nenhum dos $\operatorname{grupos}\left(\mathrm{F}_{[2,36]}=1,362, \mathrm{P}=0,269\right)$.

Este mesmo comportamento não foi diferente para os animais do grupo lesado ao longo da primeira sessão $\left(\mathrm{F}_{[4,56]}=1,963, \mathrm{P}=0,117\right)$. A comparação do primeiro minuto da primeira sessão não foi diferente para nenhum dos grupos $\left(\mathrm{F}_{[2,36]}=1,362, \mathrm{P}\right.$ $=0,269)$. O tempo utilizado no comportamento de mergulhar para o grupo controle foi diferente ao longo da primeira sessão $\left(\mathrm{F}_{[4,44]}=3,344, \mathrm{P}=0,018\right)$, sendo menor o minuto 4 quando comparado com o minuto 1 (teste de Bonferroni).

O grupo injetado com salina também foi diferente ao longo da primeira sessão $\left(\mathrm{F}_{[4,44]}=3,815, \mathrm{P}=0,010\right)$, sendo menores os tempos nos minutos 3 e 4 quando comparados com o minuto 1(teste de Bonferroni). O tempo de mergulhar a cabeça durante a primeira sessão para os animais do grupo lesado não foi diferente ao longo da primeira sessão $\left(\mathrm{F}_{[4,56]}=0,925, \mathrm{P}=0,456\right)$.

A comparação do tempo gasto mergulhando a cabeça no primeiro minuto da primeira sessão não foi diferente quando comparados os três grupos $\left(\mathrm{F} 2_{[2,36]}=0,709, \mathrm{P}\right.$ $=0,499)$. 

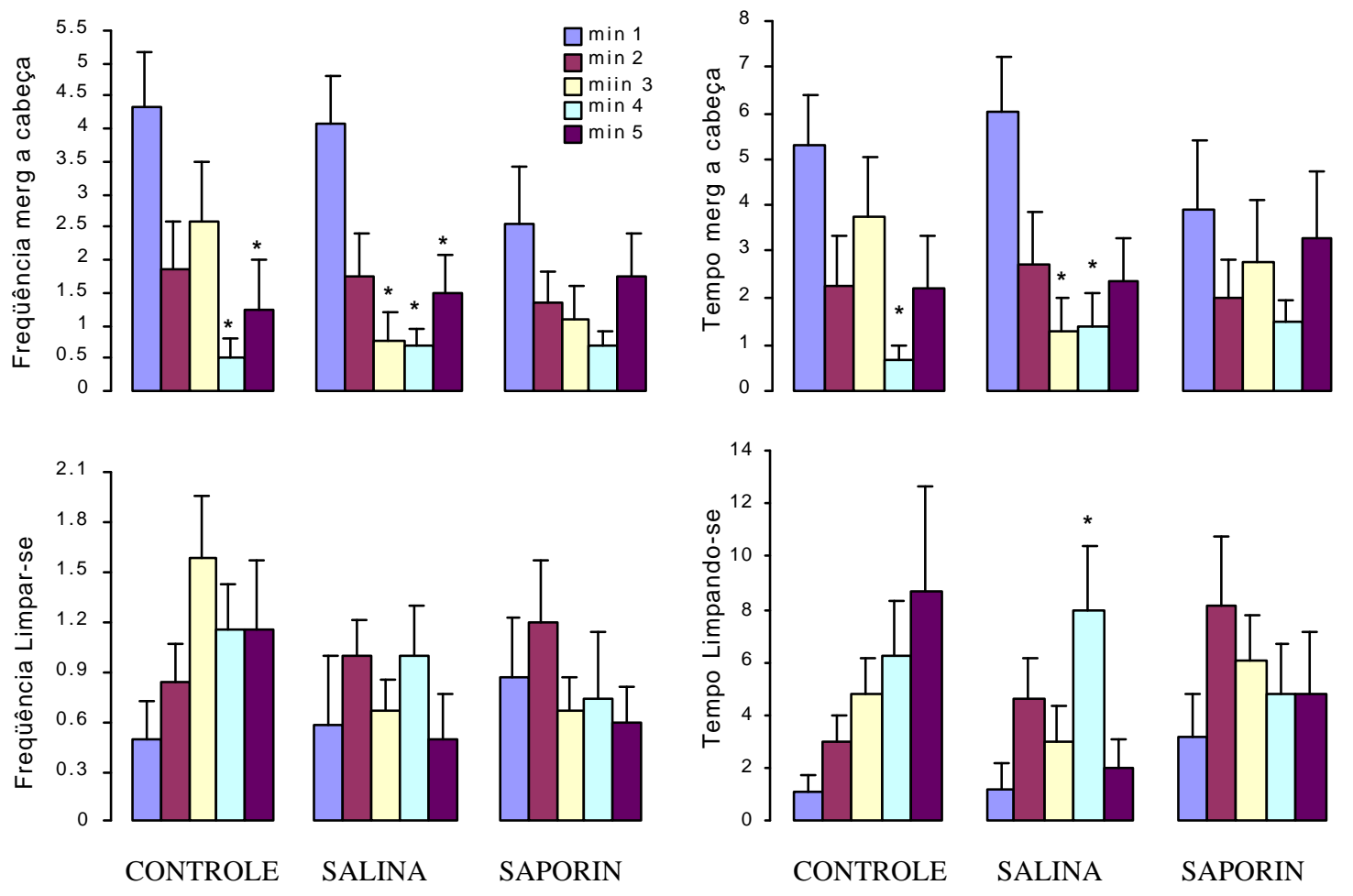

Figura 11: Freqüências e tempos (média \pm EPM) durante os cinco minutos para os comportamentos de mergulhar a cabeça e limpar-se na primeira sessão do labirinto para todos os grupos. *, diferente do primeiro minuto do mesmo grupo.

A freqüência de limpar-se ao longo dos cinco minutos da primeira sessão não foi diferente para o grupo controle $\left(\mathrm{F}_{[4,44]}=1,963, \mathrm{P}=0,117\right)$, nem para o salina $\left(\mathrm{F}_{[4,44]}\right.$ $=1,717, \mathrm{P}=0,585)$, e tampouco para o lesado com saporin $\left(\mathrm{F}_{[4,44]}=0,606, \mathrm{P}=0,660\right)$. A duração deste comportamento ao longo dos cinco minutos foi semelhante para os grupos controle $\left(\mathrm{F}_{[4,44]}=1,960, \mathrm{P}=0,117\right)$ e lesado $\left(\mathrm{F}_{[4,56]}=0,841, \mathrm{P}=0,505\right)$ mas diferiu para os animais do grupo salina $\left(\mathrm{F}_{[4,44]}=2,759, \mathrm{P}=0,039\right)$, no qual os animais limparam-se no minuto 4 mais tempo do que no primeiro minuto. Os três grupos de ratos limparam-se com frequiência $\left(\mathrm{F}_{[2,36]}=0,317, \mathrm{P}=0,730\right)$ e duração $\left(\mathrm{F}_{[2,36]}=1,280\right.$, $\mathrm{P}=0,368$ ) semelhantes no primeiro minuto da primeira sessão (Figura 11). 


\section{D I S C US S Ã O}

Análise bioquímica: Os resultados da análise bioquímica mostraram uma queda significativa na atividade da acetilcolinesterase no hipocampo, no septo e no córtex pré-frontal para o grupo que recebeu IgG 192-saporin, comparado com os animais controle e os injetados com solução salina. A redução nos níveis de acetilcolinesterase no septo e no hipocampo é consistente com os trabalhos que fazem uso dessa mesma imunotoxina (Willey et al., 1991; Torres et al., 1994; Berger-Sweeney et al., 1994; Baxter et al., 1995, 1996; Shen et al., 1996; Walsh et al., 1996).

A diminuição dos níveis da acetilcolinesterase no córtex pré-frontal poderia ser explicada pela difusão da imunotoxina nas regiões do núcleo basal magnocelular, próximas ao local da injeção (que também contêm populações de neurônios colinérgicos sensíveis ao saporin), e que se projetam para todo o córtex (Amaral e Kurz, 1985; Freund e Antal, 1988; Saper, 1984; Messulam, 1995; Izquierdo e Medina, 1997; Wenk, 1997). Um artigo recente (Chapell et. al, 1998) chega mesmo a introduzir modificações na injeção do saporin no núcleo septal medial, dividindo o volume total a ser injetado em duas aplicações menores, em uma tentativa de contornar o problema da difusão.

Atividade geral: Os índices de atividade geral, (a) a distância total percorrida e distância percorrida nos braços fechados, (b) freqüência de entradas e tempo de permanência nas extremidades dos braços fechados, (c) a frequiência de entradas e o tempo de permanência nos braços fechados do labirinto, e (d) o total de entradas nos dois tipos de braços, não foram diferentes para os grupos quando analisados os totais de cada sessão de cinco minutos, permitindo concluir que a lesão do componente 
colinérgico da projeção septo-hipocampal não interfere com a atividade exploratória (ver adiante, no entanto, as diferenças quando se consideram as medidas minuto a minuto). Quando se comparam a primeira e segunda sessões, contudo, a atividade exploratória dos grupos não lesados diminuiu enquanto a dos lesados permaneceu similar. Esta queda na exploração na segunda sessão pode ser interpretada como um efeito do reconhecimento espacial feito pelos roedores na primeira apresentação ao labirinto, efeito esse já relatado por Rodgers e colaboradores (1996), usando camundongos. A ausência do mesmo efeito nos animais lesados com saporin permite sugerir uma interrupção no armazenamento e/ou recuperação da informação espacial, o que apóia relatos anteriores sobre o efeito de lesões imunotóxicas do núcleo septal medial sobre a aprendizagem de tarefas espaciais (Berger-Sweeney et al., 1994; Walsh et al., 1996). Os resultados do presente estudo são compatíveis com essa interrupção na aprendizagem de tarefas espaciais obtida após a injeção de antagonistas muscarínicos e neurotoxinas colinérgicas no hipocampo (Walsh e Chrobak, 1991) e reflete a importância do sistema colinérgico septo-hipocampal no armazenamento e recuperação da informação normalmente associada a um ambiente novo. Sabe-se que as projeções colinérgicas e GABAérgicas da via septo-hipocampal modulam a excitabilidade do hipocampo e sua capacidade para responder à informação que chega através do córtex. A acetilcolina despolariza neurônios hipocampais fechando canais de potássio (induzindo a chamada corrente $\mathrm{M}$ ), prolongando assim a duração do potencial excitatório (Freund e Antal, 1988; Foster e Deadwyler, 1992). A destruição total ou parcial dessa via colinérgica produz dificuldades na aquisição de informação e, no caso específico da exploração do labirinto em cruz elevado, na identificação dos aspectos espaciais relevantes com a conseqüente diminuição da exploração observada 
nos animais não lesados, tanto no presente experimento como em experimentos feitos com outros roedores (Rodgers et al., 1996).

Comportamentos associados à ansiedade: A freqüência de entradas e o tempo de permanência nos braços abertos do labirinto não foram significativamente alterados por nenhum dos tratamentos, quando considerados os totais das duas sessões de cinco minutos. Este resultado contrasta com relatos anteriores (Gray, 1982, 1984; Treit e Pesold, 1990; Pesold e Treit, 1992, 1994, 1995, 1996; Menard e Treit, 1996 a, b; Treit e Menard, 1997), segundo os quais a lesão do septo produz um efeito comportamental semelhante ao observado após a injeção de drogas ansiolíticas em diversos modelos animais de ansiedade, inclusive no labirinto em cruz elevado. Porém, esses estudos foram baseados em lesões de regiões amplas (geralmente incluindo o septo medial e o septo lateral, assim como a banda diagonal de Broca em toda sua extensão). Adicionalmente, as técnicas de lesão utilizadas foram em sua maior parte eletrolíticas ou excito-tóxicas, sendo que as primeiras incluem não somente corpos neuronais mas também axonios de passagem, enquanto as últimas, mesmo limitando sua ação aos corpos dos neurônios, incluem também interneurônios e células de outros tipos, como a neuroglia. Finalmente, ao contrario dos trabalhos anteriores, o presente trabalho utilizou uma toxina específica para neurônios colinérgicos, diminuindo a possibilidade de se afetar neurônios de outros tipos (como os GABAérgicos, por exemplo), que também se projetam do septo medial para o hipocampo (Freund, 1989), e que poderiam ser os responsáveis pelos resultados descritos na literatura.

Existe uma serie de trabalhos mostrando que o septo lateral, muito mais que o septo medial, poderia estar exercendo funções moduladoras da ansiedade. Tem-se relatado que a microinjeção de muscimol no septo lateral produz um efeito anticonflito dose-dependente medido no teste do beber punido (Drugan et al., 1986). Também foi 
descrito um efeito ansiolítico da estimulação elétrica do septo lateral na mesma tarefa de conflito (Yadin et al. 1992). Esse mesmo trabalho relata ainda que a lesão eletrolítica do septo lateral, coerentemente, produziu um efeito ansiogênico, isto é, uma diminuição ainda maior do beber punido. Mais recentemente, foi relatado que a microinfusão do ansiolítico benzodiazepínico midazolam no septo lateral (mas não no septo medial) suprime as reações de medo no labirinto em cruz elevado, um efeito parcialmente bloqueado pela infusão prévia de um antagonista do receptor benzodiazepínico (Pesold e Treit, 1996). Esses resultados sugerem que a divisão lateral do septo pode ser um sítio crítico para a modulação dos comportamentos relacionados com a ansiedade, através de diversos sistemas de neurotransmissão, dentre os quais o GABAérgico.

Contrariamente às comparações de cada sessão, que não mostraram diferenças atribuíveis aos tratamentos, a comparação das entradas nos braços abertos entre a primeira e a segunda sessões mostrou que os animais não lesados diminuíram a exploração dos braços abertos enquanto os lesados mantiveram o mesmo nível de exploração desses braços na segunda sessão. Esses resultados exibidos pelos ratos não lesados confirmam relatos prévios, segundo os quais, em uma segunda exposição ao labirinto em cruz elevado, ratos sem nenhum tratamento tendem a se esquivar dos braços abertos (File, 1990; File et al., 1992; Rodgers et al., 1996). Já o resultado observado com os animais lesados confirma a discussão feita com relação aos índices de atividade geral, isto é, que o efeito da lesão imunotóxica do componente colinérgico da via septo-hipocampal prejudica também o armazenamento e/ou recuperação da informação concernente aos braços abertos.

A julgar por esses resultados, seria de se esperar que as freqüências e durações das entradas nas extremidades abertas, bem como as distâncias percorridas nos braços 
abertos, também diminuíssem na segunda sessão para os animais não lesados. Isso no entanto não aconteceu, e os animais exploraram as extremidades abertas e locomoveram-se pelos braços abertos de modo semelhante tanto na primeira quanto na segunda sessão. Esses resultados contrastam nitidamente com as frequiências e tempos de permanência nos braços abertos, para esses mesmos grupos, já que os lesados apresentaram valores semelhantes em todas as medidas associadas com ansiedade. Não se tem explicações para essa discrepância, nem tampouco existem dados na literatura que corroborem essa observação.

Outros comportamentos: A freqüência de levantar-se encontra-se reduzida nos animais lesados com saporin, quando comparados aos do grupo controle, na primeira sessão. Esta queda corrobora relatos anteriores, sobre o papel dos mecanismos colinérgicos na modulação deste tipo de comportamento, considerado como parte do repertório exploratório dos roedores. Foi demonstrado que a injeção do agente colinérgico carbacol na área pré-óptica/hipotálamo anterior ou no núcleo tegmental pedúnculopontino produz um decremento na atividade locomotora e na freqüência de levantar-se (Brudzynski et al., 1986, 1988). Por outro lado, a infusão de carbacol na área septal (Monmaur et al., 1997) e no hipocampo (Flicker e Geyer, 1982) produz um aumento na frequiência de comportamentos de caráter exploratório, como levantar-se, caminhar, esquadrinhar e mover as vibrissas. Esses efeitos são bloqueados pela injeção prévia com atropina, sugerindo com esto que os receptores muscarínicos no hipocampo participam da modulação da atividade locomotora (Flicker e Geyer, 1982). Os dados relatados na literatura com a lesão por saporin, juntamente com estes resultados sugerem que o sistema colinérgico septo-hipocampal (em conjunto com outras projeções colinérgicas originadas provavelmente nos núcleos pedúnculo-pontino e tegmental laterodorsal) participa da modulação de comportamentos exploratórios, 
entre eles, o de levantar-se. Já na comparação do comportamento de levantar-se nas duas sessões, o baixo nível das freqüências de este comportamento na primeira sessão fizeram com que não se observassem diferenças na comparação com a segunda sessão dos grupos salina e saporin, enquanto o grupo controle mostrou uma queda significativa na freqüência deste comportamento na segunda sessão.

O comportamento de esticar-se do grupo saporin não se alterou em comparação aos controles, nem na primeira nem na segunda sessão. Esses resultados parecem indicar que a lesão dos neurônios colinérgicos do septo medial não afeta esse comportamento, o qual tem sido principalmente associado a funções de avaliação de risco em situações potencialmente perigosas, incrementando-se após a aplicação de fármacos ansiolíticos (Cruz et al., 1994; Rodgers e Johnson, 1995; Anseloni e Brandão, 1997).

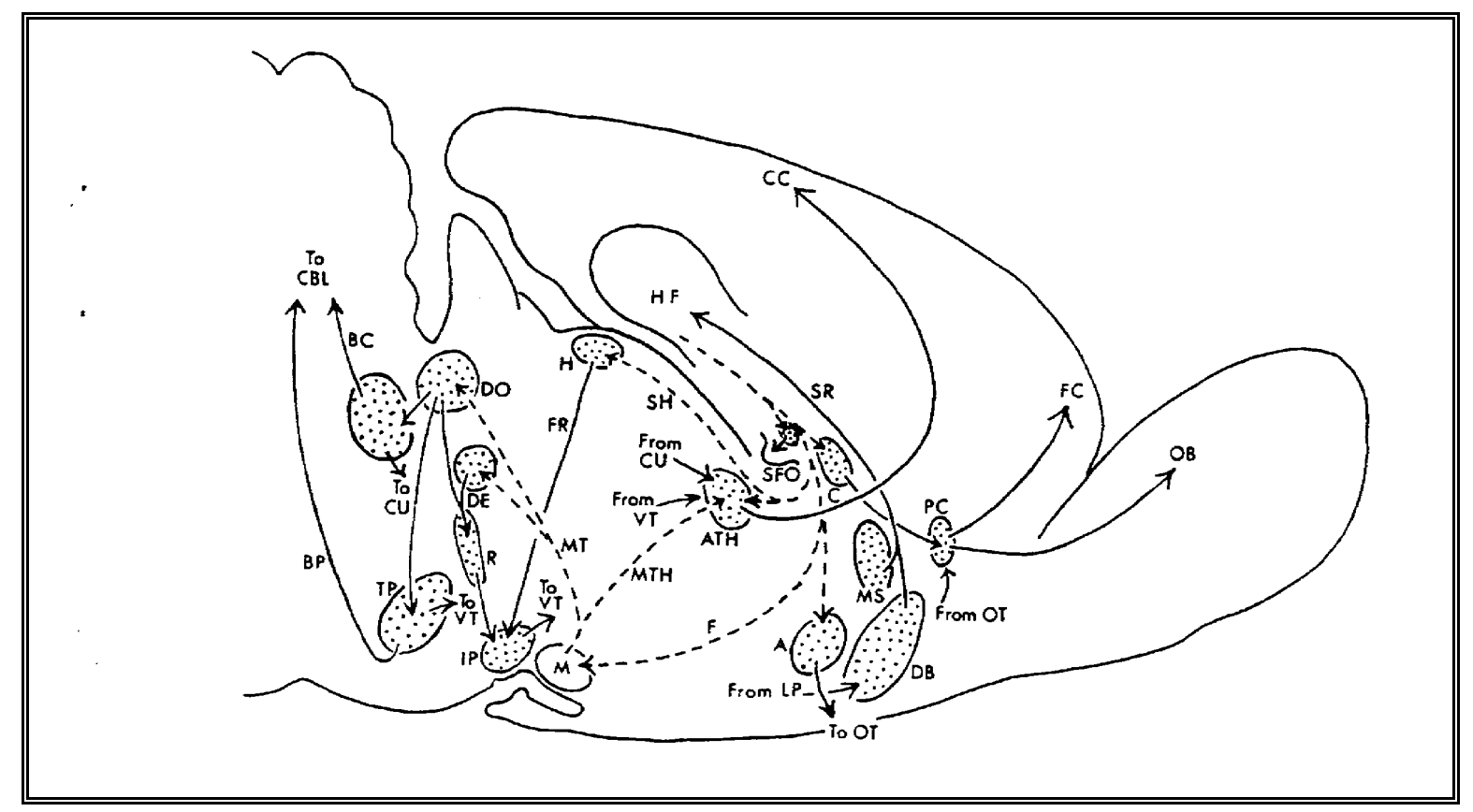

Quadro 2. Núcleos colinérgicos mesencefálicos e prosencefálicos no cérebro do rato. MS, septo medial; HP, hipocampo; LD, núcleo tegmental laterodorsal; IP, núcleo interpeduncular (De Lewis e Shute, 1967) 
A freqüência e o tempo do comportamento de mergulhar a cabeça não foi diferente para os grupos, em cada uma das duas sessões de cinco minutos. Porém, as comparações entre as sessões indicam uma queda na freqüência deste comportamento na segunda sessão dos grupos controle e salina mas não dos animais lesados. Essa observação correlaciona-se com os resultados obtidos com o efeito da lesão sobre os índices da atividade geral. Mergulhar a cabeça é um comportamento associado a estratégias de busca de informações em um ambiente novo (Cruz et al., 1994; Rodgers e Johnson, 1995; Anseloni e Brandão, 1997), e pode ser considerado como uma parte integral do comportamento exploratório, complementando os déficits observados nos outros índices de atividade exploratória (entradas nos braços fechados, distancia percorrida etc.)

Finalmente, o comportamento de limpar-se não se mostrou afetado pela lesão em nenhuma das duas sessões. A comparação entre sessões, no entanto, mostrou que os grupos controle e salina, por mais tempo na segunda sessão, enquanto o grupo lesado não mostra qualquer diferença. Este aumento no tempo de limpeza pelos grupos controle e salina pode ser explicado em termos de uma compensação pela diminuição do comportamento exploratório durante a segunda sessão do labirinto observada em esses animais não lesados.

Análise minuto a minuto da primeira sessão: A comparação minuto a minuto da distância percorrida no braço aberto mostrou que os grupos controle e salina diminuíram a distância percorrida na primeira sessão ao longo dos 5 minutos de duração da sessão; essa diminuição gradual não ocorreu com o grupo lesado pelo saporin. Analisando-se apenas os totais da sessão não é possível mostrar esse efeito. Essa análise minuto a minuto confirmam os achados sobre o efeito da lesão no 
comportamento exploratório e no armazenamento e/ou recuperação da informação. Resultados semelhantes podem ser observados na distância percorrida nos braços fechados e na distância total percorrida nos quatro braços do labirinto, confirmando igualmente o efeito da lesão com saporin. Porém, nesses dois últimos índices observase um nível inferior de atividade durante o primeiro minuto apenas para os animais do grupo lesado com saporin. Esse valor inferior pode ser explicado pelos achados sobre o papel do sistema colinérgico septo-hipocampal (em conjunto com outras projeções colinérgicas originadas provavelmente nos núcleos pedúnculo-pontino e tegmental laterodorsal) na modulação do comportamento exploratório (Flicker e Geyer, 1982; Brudzynski et al., 1986, 1988; Monmaur et al., 1997).

O número de entradas ao longo da sessão apresenta um perfil semelhante ao observado na distância percorrida, ou seja o total de entradas diminui gradativamente ao longo da primeira sessão nos grupos controle e salina, mas não no grupo lesado. Essa diminuição gradual pode ser atribuída tanto a diminuições nas entradas nos braços abertos como nos braços fechados. Observa-se igualmente uma freqüência menor de entradas totais e de entradas nos braços fechados (mas não nos abertos) durante o primeiro minuto pelo grupo lesado. A análise do tempo de permanência nos braços abertos para os animais do grupo controle e salina, mostrou uma queda gradativa ao longo dos cinco minutos da primeira sessão. Este resultado não foi observado no grupo lesado. Diferentemente do observado com a freqüência de entradas, o tempo de permanência nos braços abertos durante o primeiro minuto não foi diferente para nenhum dos grupos. Este achado reflete um efeito específico da lesão colinérgica pelo saporin sobre a atividade exploratória em termos de busca de informação no labirinto. 
Com relação à análise por minuto dos demais comportamentos, observou-se uma diminuição na frequiência de esticar-se, ao longo da primeira sessão, para os animais do grupo controle (sendo significativa, porém, somente a diferença entre os minutos 1 e 5), enquanto os grupos salina e saporin não apresentaram essa queda. Esses resultados são semelhantes aos observados quando da comparação entre a primeira e segunda sessões. Porém, o fato de se ter obtido discrepância entre os resultados dos grupos controle e salina permite sugerir algum tipo de lesão mecânica nesses últimos. Esses resultados vão na mesma direção dos obtidos sobre a ausência de efeitos da lesão nos comportamentos de avaliação de risco.

O comportamento de mergulhar a cabeça mostrou um perfil decrescente similar ao observado nas entradas e na distância percorrida, com a manutenção do comportamento pelos animais lesados ao longo da sessão. Essa diminuição é semelhante àquela evidenciada na comparação entre as duas sessões (o comportamento de mergulhar a cabeça não apresenta queda entre a primeira e a segunda sessões para os animais lesados). O comportamento de mergulhar a cabeça tem sido associado a estratégias de procura de informação e, no contexto do presente estudo, parece coerente com o observado nos outros índices de atividade exploratória.

Finalmente, a frequiência de limpar-se dos animais dos grupos controle e salina diminuiu gradualmente ao longo dos cinco minutos da sessão, enquanto os animais do grupo lesado não apresentaram essa diminuição. O tempo gasto realizando este comportamento também caiu ao longo da sessão para os animais controle e salina mas não para os animais do grupo lesado. Esses resultados vão na mesma direção dos efeitos da lesão sobre os demais comportamentos, isto é, manutenção dos comportamentos associados à exploração e diminuição gradual dos comportamentos não associados a ela, como é o caso da limpeza. 
Em geral, a análise minuto a minuto dos diferentes comportamentos acrescentou informação valiosa, que não era evidente quando se comparam os totais de respostas para sessões inteiras. Assim pode constituir uma metodologia promissora no estudo da ansiedade e da memória.

\section{C O N C L U S Õ E S G E R A I S}

Os resultados mostraram que a lesão imunotóxica do componente colinérgico do núcleo septal medial afeta a exploração no labirinto em cruz elevado, sem afetar os índices de ansiedade. Esse efeito diferencial na exploração está de acordo com os déficits observados em alguns testes de aprendizagem espacial após o mesmo tipo de lesão imunotóxica que a utilizada aqui (Walsh et al., 1996; Shen et al., 1996; Dornan et al., 1997) e pode ser interpretado em termos de uma modificação no padrão comportamental exploratório mostrado por ratos e camundongos quando submetidos a ambientes novos.

Tem sido sugerido que esse padrão comportamental é o resultado da retenção de informação espacial, que pode ser evidenciada a partir do segundo minuto de exploração, quando os animais diminuem a frequiência de entradas nos braços do labirinto (Rodgers, 1996). A análise comportamental minuto a minuto dos animais controle e injetados com salina confirmam este fato, e a ausência dessa diminuição na exploração nos animais lesados permite sugerir um déficit no processo de armazenamento e/ou recuperação da informação. Foram propostos diversos mecanismos cerebrais hipoteticamente envolvidos na modulação dessas funções mnemônicas. Dois desses mecanismos, a potencialização e a depressão de longo prazo, 
observados em diversas estruturas, são mais caracteristicamente descritos no caso do hipocampo (Bliss e Lomo, 1973; Martínez e Derrick, 1996; Jerusalinsky et al., 1997; Izquierdo e Medina, 1997). A indução de potencialização de longo prazo parece ser mediada por mecanismos excitatórios glutamatérgicos. Acredita-se que as projeções colinérgicas oriundas do núcleo septal medial e banda diagonal participam dessa mediação, já que inervam todos os tipos de células no hipocampo, incluindo os neurônios piramidais, as células granulares do giro denteado e os interneurônios GABAérgicos distribuidos no hipocampo inteiro, os quais inibem outros neurônios GABAérgicos (Walsh et al., 1996, 1998). Dessa forma, as fibras colinérgicas que se originam no septo medial ativam diretamente o hipocampo por meio das células excitatórias glutamatérgicas e indiretamente através da inibição dos interneurônios GABAérgicos, modulando sua atividade elétrica e a indução da potencialização de longo prazo (Freund e Antal, 1988; Foster e Deadwyler, 1992; Vinogradova, 1995; Walsh et al., 1996, 1998; Natsume e Kometani, 1997; Apartis et al., 1998). Entretanto, é importante lembrar que uma população diferente de neurônios do septo medial projeta-se para o córtex do cíngulo (Amaral e Kurz, 1985), mas essa conexão tem sido ignorada na avaliação dos efeitos comportamentais das lesões colinérgicas da via septo-hipocampal. As lesões do córtex do cíngulo em ratos e macacos produzem déficits de memória espacial qualitativamente similares aos observados após lesão da fimbria-fórnix (Markowska et al., 1989). Adicionalmente, Marston e colaboradores (1994) relataram que a lesão excito-tóxica do septo medial afeta a aquisição de tarefas de discriminação complexa, sendo esses déficits correlacionados com a perda da atividade da colina acetiltransferase (enzima que metaboliza a acetilcolina) no cíngulo, mas não no hipocampo. Dessa forma, a comunicação colinérgica entre o septo e o 
cíngulo pode ter um papel importante na modulação da memória, e deve ser incluída na análise dos efeitos de lesões do núcleo septal medial.

Recentemente, têm se relatado resultados contraditórios sobre os efeitos da lesão do componente colinérgico da via septo-hipocampal com saporin em tarefas de aprendizagem espacial. Alguns autores tem encontrado efeitos moderados ou nenhum efeito na aprendizagem no labirinto aquático de Morris (Berger-Sweeney et al., 1994; Torres et al., 1994; Baxter et al., 1995, 1996; Bannon et al., 1996) e numa tarefa de memória de trabalho espacial no labirinto radial, usando comida como reforço (Chapell et al., 1998). Entretanto, outros autores tem relatado déficits significativos após a lesão do septo medial com saporin em tarefas de memória de trabalho espacial com reforço alimentar (Walsh et al., 1996; Shen et al., 1996; Dornan et al., 1997), assim como em tarefas de aprendizagem operante com componente de memória de trabalho (Torres et al., 1994). Janis e colaboradores (1998), discutiram esses resultados sugerindo que os diferentes tipos de tarefa requeridos em cada estudo poderiam ser a origem da contradição. Por exemplo, os trabalhos de Walsh e colaboradores (1996) e Shen e colaboradores (1996) utilizaram uma tarefa complexa de localização espacial, na qual combinam-se estratégias egocêntricas (dependentes do sujeito) e alocêntricas (dependentes do entorno). Os estudos que usam o labirinto aquático de Morris com a plataforma visível (Berger-Sweeney, 1994; Janis, et al., 1998) apresentam resultados semelhantes aos observados no labirinto radial. Já os estudos com labirinto aquático com a plataforma submersa não apresentam déficits decorrentes da lesão do núcleo septal medial com saporin (Torres et al., 1994; Baxter et al., 1995, 1996; Bannon et al., 1996).

Possivelmente, nas tarefas de labirinto radial e de labirinto aquático com plataforma visível, os animais normais servem-se de sinais espaciais para a localização 
dos seus objetivos (comida ou fuga da água), enquanto os animais com lesão colinérgica septal parecem ser incapazes de usar essa mesma estratégia. Já os estudos com labirinto aquático com plataforma submersa não oferecem a opção dos sinais espaciais, sendo o reconhecimento do local de fuga inteiramente dependente de estratégias egocêntricas, que parecem não ser afetadas pela lesão com o saporin.

Os nossos resultados apresentam uma alternativa interessante, já que correspondem ao comportamento espontâneo dos animais frente a uma situação nova. Na situação que os animais enfrentam no labirinto em cruz elevado, as diferentes áreas (abertas ou fechadas) têm características próprias que podem funcionar como sinais de identificação. Nesse sentido, os nossos dados apóiam os resultados obtidos por Walsh e colaboradores (1996), Shen e colaboradores (1996) e Janis e colaboradores (1998), permitindo sugerir que processos de memória de trabalho espacial fazem parte do repertório comportamental dos ratos durante a exploração do labirinto em cruz elevado, e que essas estratégias estão de alguma forma moduladas pela projeção colinérgica septo-hipocampal.

No entanto, o fato de ter obtido baixos níveis de absorbância de acetilcolinesterase no córtex pré-frontal dos animais lesados não permite concluir um envolvimento exclusivo da via septo-hipocampal nos déficits comportamentais observados. A queda desses níveis de absorbância podem ser o resultado da difusão da toxina para as áreas próximas do núcleo basal magnocelular, o qual tem neurônios colinérgicos sensíveis à ação do saporin (Willey et al. 1991; Torres et al., 1994). Esse núcleo projeta-se ao córtex e à amígdala e tem sido associadas a funções de armazenamento e recuperação de informação (Torres et al., 1994). Lesões imnunotóxicas desse núcleo com saporin resultaram em déficits de aprendizagem de tarefas de navegação espacial sem sinais ambientais (no labirinto aquático de Morris), 
enquanto a mesma tarefa com ajuda de sinais espaciais não foi afetada (Berger-

Sweeney, 1996). Esses resultados corroboram o papel da via septo-hipocampal (e não

da baso-cortical) no armazenamento e recuperação de informações espaciais, que no nosso estudo foram afetadas pela lesão com saporin. Outros estudos, porém, serão necessários para que se possa chegar a conclusões mais definitivas.

\section{R E F E R Ê N C I A S B I B L I O G R Á F I C A S}

Alpern HP e Marriott JG (1973). Short term memory: Facilitation and disruption with cholinergic agents. Physiology and Behavior, 11: 571-575.

Amaral DG e Kurz J (1985). An analysis of the origin of the cholinergic and non-cholinergic septal projections to the hippocampal formation of the rat. The Journal of Comparative Neurology, 240: 37-59.

Anseloni VZ e Brandão ML (1997). Ethopharmacological analysis of behavior of rats using variations of the elevated plus maze. Behavioral Pharmacology, 8: 533-540.

Apartis E, Poidessous-Jasat FR, Lamour YA; Bassant MH (1998). Loss of rhythmically bursting neurons in rat medial septum following selective lesions of septohipocampal cholinergic system. Journal of Neurophysiology, 79: 1633-1642.

Atkinson RC e Shiffrin JM (1968). Human memory: A proposed system and its control processes. Em Spence KW e Spence JT (editores), The psychology of learning and motivation: Advances in research and theory. Academic Press, New York. p. 89-195.

Augustinsson KB, Eriksson H e Faijersson Y (1978). A new approach to determining cholinesterase activities in samples of whole blood. Clinica Chimica Acta, 89: 239-252.

Bannon AW, Curzon P, Gunther KL e Decker MW (1996). Effects of intraseptal injection of 192-IgGsaporin in mature and aged Long-Evans rats. Brain Research, 718: 25-36.

Barnett SA (1956). Behaviour components in the feeding of wild and laboratory rats. Behaviour, 9: 2443.

Barnett SA (1958). Exploratory behavior. The British Journal of Psychology, 49: 289-310.

Barone S, Nanry KP, Mundy WR, McGynty JF e Tilson HA (1991). Spatial learning deficits are not solely due to cholinergic deficits following medial septal lesions with colchicine. Psychobiology, 19: 41-50.

Bassant MH, Apartis E, Jazat-Poindessous FR, Wiley RG e Lamour YA (1995). Selective immunolesion of the basal forebrain cholinergic neurons: effects on hippocampal activity during sleep and wakefulness in the rat. Neurodegeneration, 4: 61-70.

Baxter MG, Buccy DJ, Gorman LK, Wiley RG e Gallagher M (1995). Selective immunotoxic lesions of basal forebrain cholinergic cells: Effects on learning and memory in rats. Behavioral Neuroscience, 109: 714-722.

Baxter MG, Buccy DJ, Sobel TJ, Williams MJ, Gorman LK e Gallagher M (1996). Intact spatial learning following lesions of basal forebrain cholinergic neurons. Neuroreport, 7: 1417-1420.

Berger-Sweeney J, Heckers S, Mesulam MM, Wiley RG, Lappi DA e Sharma M (1994). Differential effects on spatial navigation of immunotoxin-induced cholinergic lesions of the medial septal area and Nucleus Basalis Magnocellularis. The Journal of Neuroscience, 14: 4507-4519.

Berlyne DE (1950). Novelty and curiosity as determinants of exploratory behavior. British Journal of Psychology, 41: 68-80. 
Berlyne DE (1951). Attention to change. British Journal of Psychology, 42: 269-278.

Blanchard DC e Blanchard RJ (1988). Ethoexperimental approaches to the biology of emotion. Annual Reviews, Palo Alto.

Blanchard DC, Blanchard RJ, Tom P e Rodgers RJ (1990). Diazepam changes risk assessment in an anxiety/defense test battery. Psychopharmacology, 101: 511-518.

Blanchard RJ e Blanchard DC (1990). An ethopharmacological analysis of defense, fear and anxiety. Em McNaughton N e Andrews G (editores), Anxiety. University of Otago Press, Dunedin. p. 124-33.

Blanchard RJ, Blanchard DC, Flannelly KJ e Hon K (1986). Ethanol changes patterns of defensive behavior in wild rats. Physiology and Behavior, 38: 645-650.

Bland BH, Trepel C, Oddie SD e Kirk IJ (1996). Intraseptal microinfusion of muscimol: effects on hippocampal formation theta field activity and fascic theta - on cell discharges. Expeimental Neurology, 138: 286-297.

Bliss TVP e Lomo T (1973). Long-lasting potentiation of synaptic transmission in the dentate area of the anesthetized rabbit following stimulation of the perforant path. Journal of Physiology, 232: $331-356$

Bloom FE (1996). Neurotransmission and the central nervous system. Em Hardman JG, Gilman AG e Limbird LE (1996). Goodman \& Gilman's The Pharmacological Basis of Therapeutics. McGraw-Hill, Nova York: 267-293.

Brady JB e Nauta WJ (1953). Subcortical mechanisms in emotional behavior: Affective changes following septal forebrain lesions in the albino rat. Journal of Comparative Physiological Psychology, 46: 339-346.

Brady JB e Nauta WJ (1955). Subcortical mechanisms in control of behavior. Journal of Comparative Physiological Psychology, 48: 412-420.

Brioni JD, O’Neill AB, Kim DJ e Decker MW (1993). Nicotinic receptor agonists exhibit anxiolyticlike effects on the elevated plus maze test. European Journal of Pharmachology 238: 1-8

Brioni JD, O’Neill AB, Kim DJ, Buckley MJ, Decker MW e Arneric SP (1994). Anxiolytic-like effects of the novel cholinergic chanel activator ABT-418. Journal of Pharmachology and Experimental Therapy 271: 353-361

Brudzynski SM e Mogenson GJ (1986). Inhibition of amphetamine-induced locomotor activity by injection of carbachol into the anterior hypothalamic-preoptic area: Pharmacological and electrophysiological studies in the rat. Brain Research, 376: 47-56.

Brudzynski SM, Wu M e Mogenson GJ (1988). Modulation of locomotor activity induced by injections of carbachol into the tegmental pedunculopontine nucleus and adjacent areas in the rat. Brain Research, 451: 119-125.

Butler RA (1953). Discrimination learning by rhesus monkeys to visual - exploration motivation. Journal of Comparative Physiological Psychology, 46: 95-98.

Buzsaki G, Leungh WW e Vanderwolf CH (1983). Cellular basis of hippocampal EEG in the behaving rat. Brain Research Review, 6: 139-171.

Carlson NE (1994). Physiology of Behavior. Allyn and Bacon, Boston, Capítulo 3: 61-75.

Chapell J, McMahan R, Chiba A e Gallagher M (1998). A re-examination of the role of basal forebrain cholinergic neurons in spatial working memory. Neuropharmacology, 37: 481-487.

Chrobak JJ, Stackman RW e Walsh TJ (1989). Intraseptal administration of muscimol produce dose dependent memory impairments in the rat. Behavioral and Neural Biology, 52: 357-369.

Cruz APM, Frei F e Graeff FG (1994). Ethopharmacological analysis of rat behavior on the elevated plus maze. Pharmacology Biochemistry and Behavior, 49: 171-179.

Cunha C, Destein ML, Wolfman C, Koya R, Izquierdo I e Medina JH (1992). Effect of various training procedures on performance in an elevated plus maze - possible relation with brain regional levels of benzodiazepine-like molecules. Pharmacology Biochemistry and Behavior, 43: 677681. 
Decker MW, Curzon P, Brioni JD e Arneri'c SP (1994). Effects of ABT-418, a novel cholinergic channel ligand, on a place learning in septal-lesioned rats. European Journal of Pharmachology, 261: 217-222.

Deutsch JA (1971). The cholinergic synapse and the site of memory. Science, 174: 788-794.

Dornan WA, McCampbell AR, Tinkler GP, Hickman LJ, Bannon AW, Decker MW e Gunther KL (1997). Comparison of site specific injections into the basal forebrain on water-maze and radial arm maze performance in the male rat after immunolesioning with 192-IgG-saporin. Behavioral Brain Research, 86: 181-189.

Drugan RC, Skolnick P, Paul SM e Crawley JM (1986). Low doses of muscimol produce anticonflict actions in the lateral septum of the rat. Neuropharmacology, 25: 203-205.

Ehlert JE, Roeske WR e Yamamura HI (1995). Molecular biology, pharmacology and brain distribution of subtypes of the muscarinic receptor. Em Bloom FE e Kupfer DJ (eds), Psychopharmacology: The Fourth Generation of Progress. Raven Press, Nova York: 111124.

File S (1990). One trial tolerance to the anxiolytic effects of chlordiazepoxide in the plus-maze. Psychopharmacology, 100: 281-282.

File S (1993). The interplay of learning and anxiety in the elevated plus maze. Behavioral Brain Research, 58: 199-202.

File S, Andrews N, Wu PY, Zharkovsky A e Zangrossi JH (1992). Modification of chlordiazepoxide's behavioral and neurochemical effects by handling and plus maze experience. European Journal of Pharmachology, 218: 9-14.

File S, Gonzalez LE e Andrews N (1998). Endogenous acetylcholine in the dorsal hippocampus reduces anxiety through actions on nicotinic and muscarinic1 receptors. Behavioral Neuroscience, 112: 352-359.

File S, Mabutt PS e Hitchott PK (1990). Characterization of the phenomenon of "one trial tolerance" to the anxiolytic effect of chlordiazepoxide in the elevated plus maze. Psychopharmacology, 102: $98-101$.

Fischer W, Gage FH e Bjorklund A (1989). Degenerative changes in forebrain cholinergic nuclei correlate with cognitive impairments in aged rats. European Journal of Neuroscience, 1: 3445 .

Flicker C e Geyer MA (1982). Behavior during hippocampal microinfusions II: Muscarinic locomotor activation. Brain Research, 257: 105-127.

Foster TC e Deadwyler SA (1992). Acethylcoline modulates averaged sensory evoked responses and perforant path evoked field potentials in the rat dentate gyrus Brain Research, 587: 95-101.

Foster TC, Hampson RE, West MO e Deadwyler SA (1988). Control of sensory activation of granule cells in the fascia dentata by extrinsic afferents: septal and entorhinal inputs. The Journal of Neuroscience, 8: 3869-3878.

Freund TF (1989). GABAergic septohippocampal neurons contain parvalbumin. Brain Research, 478: 375-391.

Freund TF e Antal M (1988). GABA-containing neurons in the septum control inhibitory interneurons in the hippocampus. Nature, 336: 170-173.

Frotscher M e Leranth C (1985). Cholinergic innervation of the rat hippocampus as revealed by choline acetyltransferase immunocytochemistry: a combined light and electro microscopic study. The Journal of Comparative Neurology, 239: 237-246.

Fuster JM (1995). Memory in the Cerebral Cortex: An Empirical Appraoach to Neural Networks in the Human and Non - Human Primate. MIT Press, Boston.

Graeff FG (1989). Drogas psicotrópicas e seu modo de ação. 2 ed. Editora Pedagógica e Universitaria Ltda. São Paulo.

Graeff FG (1990). Brain defense systems and anxiety. Em Roth M, Burrows GD e Noyes R (editores), Handbook of anxiety. Elsevier, Amsterdan. p. 307-54. 
Graeff FG (1994). Neuroanatomy and neurotransmitter regulation of defensive behaviors and related emotions in mammals. Brazilian Journal of Medicine and Biological Research, 27: 811-830.

Graeff FG, Silveira MC, Nogueira RL, Audi EA e Oliveira RM (1993). Role of the amygdala and periaqueductal gray in anxiety and panic. Behavioral Brain Research, 58: 123-131.

Gray JA (1982). The neuropsychology of anxiety: An enquiry into the functions of the septohippocampal system. Oxford University Press, New York.

Gray JA (1984). The hippocampus as an interface between cognition and emotion. Em Roitblat HL, Bever IG e Terrace HS (editores), Animal cognition: Proceedings of the Harry Frank Guggenheim Conference. Lawrence ErlbaumAssociates, Hillsdale. p. 607-27.

Gray JA e McNaughton N (1983). Comparison between the behavioral effects of septal and hippocampal lesions: A review. Neuroscience and Bio-behavioral Reviews, 7: 117-188.

Handley SL e Mithani S (1984). Effects of alpha-adrenoceptor agonists and antagonists in a maze exploration model of "fear" motivated behavior. Naunyn-Schmiedeberg's Archives in Pharmacology, 327: 1-5.

Hatcher JP, Loudon JM, Hagan JJ e Clark MS (1998). Sabcomeline (SB-202026), a functionally selective $\mathrm{m} 1$ receptor partial agonist, reverses delay - induced deficits in the T-maze. Psychopharmacology, 138: 275-282.

Hlinak Z e Krejci I (1998). Concurrent administration of subeffective doses of scopolamine and MK801 produces a short term amnesia for the elevated plus maze in mice. Behavioral Brain Research, 91: 83-89.

Imperato A, Dazzi L, Obinu MC, Gessa GL e Biggio G (1994). The benzodiazepine receptor antagonist Flumazenil increases acetylcholine - release in rat hippocampus. Brain Research, 647: 167171.

Itoh J, Nabeshima T e Kameyama T (1991). Utility of an elevated plus maze for dissociation of amnesic and behavioral effects of drug in mice. European Journal of Pharmachology, 194: 71-76.

Izquierdo I (1994). Pharmacological evidence for a role of long term potentiation in memory. FASEB Journal, 8: 1139-1145.

Izquierdo I e Medina JH (1993). Role of the amygdala, hippocampus and entorhinal cortex in memory consolidation and expression. Brazilian Journal of Medicine and Biological Research, 26: 573-589.

Izquierdo I e Medina JH (1995). Correlation between the pharmacology of long term potentiation and the pharmacology of memory. Neurobiology of Learning and Memory, 63: 19-32.

Izquierdo I e Medina JH (1997). Memory formation: The sequence of biochemical events in the hippocampus and its connection to activity in other brain structures. Neurobiology of Learning and Memory, 68: 285-316.

Izquierdo I, DaCunha C, Rosat R, Jerusalinsky D, Ferreira MB e Medina JH (1992). Neurotransmitter receptors involved in memory processing by the amygdala, medial septum and hippocampus of rats. Behavioral and Neural Biology, 58: 16-26.

Janis LS, Glasier MM, Fulop Z e Stein DG (1998). Intraseptal injections of 192-IgG-saporin produce deficits for strategy selection in spatial-memory tasks. Behavioral Brain Research, 90: 23-34.

Jerusalinsky D, Kornisiuk E, Alfaro P, Quillfeldt J, Alonso M, Verde ER, Cervenansky C e Harvey A (1998). Muscarinic toxin selective for $\mathrm{m} 4$ receptors impairs memory in the rat. Neuroreport, 9: 1407-1411.

Jerusalinsky D, Kornisiuk E, e Izquierdo I (1997). Cholinergic neurotransmission and synaptic plasticity concerning memory processing. Neurochemiocal Research, 4: 507-515.

Kandel ER, Schwartz JH e Jessell TM (1995). Essentials of Neural Science and Behavior. Appleton \& Lange, Norwalk.

Kluver H e Bucy PC (1937). "Psychic blindness" and other symptoms followed by bilateral temporal lobectomy in rhesus monkeys. American Journal of Physiology, 119: 352-353. 
Kohler C e Srebro B (1980). Effects of lateral and medial septal lesions on exploratory behavior on the albino rat. Brain Research, 182: 423-440.

Lee EH, Lin YP e Yin TH (1988). Effects of lateral and medial septal lesions on various activity and reactivity measures in rats. Physiology and Behavior, 42: 97-102.

Leranth, C Deller T e Buzsáki G (1992). Intraseptal connections redefined: lack of a lateral septum to medial septum path. Brain Research, 583: 1-11.

Lewis PR e Shute CC (1967). The cholinergic limbic system: Projections to hippocampal formation, medial cortex, nuclei of the ascending cholinergic reticular system and the subfornical organ and supra-optic crest. Brain, 90: 521-537.

Lynch GS, Lucas PA e Deadwyler SA (1972). Demonstration of AChE containing neurons within the caudate nucleus of the rat. Brain Research, 45: 617-621.

Markowska AL, Olton DS, Murray EA e Gaffan DA (1989). Comparative analysis of the role of fornix and cingulate cortex in memory. Experimental Brain Research, 74: 187-201.

Marston HM, West HL, Wilkinson LS, Everitt BJ e Robbins TW (1994). Effects of excitotoxic lesions of the septum and vertical limb nucleus of the diagonal band of Broca on conditional visual discrimination: Relationship between performance and choline acetyltransferase activity in the cingulate cortex. Journal of Neuroscience, 14: 2009-2019.

Martinez JL e Derrick BE (1996). Long - term potentiation and learning. Annual Review of Psychology, 47: 173-203.

Meibach RC e Siegel A (1977). Efferent connections of the septal area in the rat: An analysis utilizing retrograde and anterograde transport methods. Brain Research, 119: 1-20.

Menard J e Treit D (1996a). Does tolerance develop to the anxiolytic effects of septal lesions? Physiology and Behavior, 59: 311-318.

Menard J e Treit D (1996b). Lateral and medial septal lesions reduce anxiety in the plus maze and probe burying tests. Physiology and Behavior, 60: 845-853.

Mesulam MM (1995). Structure and Function of Cholinergic pathways in the cerebral cortex, limbic system, basal ganglia and thalamus of the human brain. Em Bloom F e Kupfr D (editores), Psychopharmacology. Raven Press, New York.

Miller VM e Best PJ (1980). Spatial correlates of hippocampal unit activity are altered by lesions of the fimbria-fornix and entorhinal cortex. Brain Research, 194: 311-323.

Miyazaki S, Imauzumi M e Machida H (1995). The effects of anxiolytics and anxiogenics on evaluation of learning and memory in an elevated plus maze test in mice. Methods and Findings in Experimental and Clinical Pharmacology, 17: 121-127.

Miyazaki S, Imauzumi M e Onodera K (1995). Ameliorating effects of histidine on learning deficits in an elevated plus maze test in mice and the contribution of cholinergic neuronal systems. Methods and Findings in Experimental and Clinical Pharmacology, 17: 57-63.

Mizumori SJY, Barnes CA e McNaughton BL (1990). Behavioral correlates of theta - on and theta - off cells recorded from hippocampal formation of mature young and aged rats. Experimental Brain Research, 80: 579-585.

Mizumori SJY, Ward KE e Lavoie AM (1992). Medial septal modulation of entorhinal single unit activity in anesthetized and freely moving rats. Brain Research, 570: 188-197.

Monmaur P, Sharif A e M'Harzi M (1997). Involvement of central muscarinic receptors in cholinergically mediated changes in rat rearing activity. Pharmacology Biochemistry and Behavior, 58: 577-582.

Montgomery KC (1955). The relation between fear induced by novel stimulation and exploratory drive. Journal of Comparative Physiological Psychology, 48: 254-260.

Montgomery KC e Monkman JA (1955). The relation between fear and exploratory behavior. Journal of Comparative Physiological Psychology, 48: 132-136. 
Morato S e Castrechini P (1989). Effects of floor surface and environmental illumination on exploratory activity in the elevated plus maze. Brazilian Journal of Medicine and Biological Research, 22: 707-710.

Murdock BB (1982). A thedory for storage and retrieval of item and associative information. Psychological Reviews, 89: 609-626.

Natsume K e Kometani K (1997). Theta - activity - dependent and independent muscarinic facilitation of long term potentiation in guinea pig hippocampal slices. Neuroscience Research, 27: 335341.

Nicoll RA, Kauer JA e Malenka RC (1988). The current excitement in long term potentiation. Neuron, 1: 97-103.

Nielson HC, McIver AH e Boswell RS (1965). Effect of septal lesions on learning, emotionality, activity, and exploratory behavior in rats. Experimental Neurology, 11: 147-157.

Nutt DJ (1990). The pharmacology of human anxiety. Pharmacology Therapeutics, 47: 233-266.

Oddie SD e Bland BH (1998). Hippocampal formation theta activity and movement selection. Neuroscience and Biobehavioral Reviews, 22: 221-231.

O'Keefe J e Black AH (1978). Single unit and lesion experiments on the sensory inputs to the hippocampal cognitive map. Em Weiskrantz L (editor), Functions of the septo - hippocampal system. Elsevier, Amsterdam. p. 179-92.

O'Keefe J e Nadel L (1978). The Hippocampus as a Cognitive Map. Clarendon Press, Oxford.

Olton DS (1979). Mazes, maps and memory. American Psychology, 34: 583-596.

Olton DS, Walker JA e Gage FH (1978). Hippocampal connections and spatial discrimination. Brain Research, 139: 295-308.

Partlo LA e Sainsbury RS (1996). Influence of medial septal and enthorinal cortex lesions on theta activity recorded from the hippocampus and medial raphe nucleus. Physiology and Behavior, 59: 887-895.

Paxinos G e Watson C (1982). The rat brain in stereotaxic coordinates. Academic Press, San Diego.

Pellow S, Chopin P, File S e Briley M (1985). Validation of open:closed arm entries in an elevated plusmaze as a measure of anxiety in the rat. Journal of Neuroscience Methods, 14: 149-167.

Pesold C e Treit D (1992). Excitotoxic lesions of the septum produce anxiolytic effects in the elevated plus maze and the shock-probe burying tests. Physiology and Behavior, 52: 37-47.

Pesold C e Treit D (1994). The septum and amygdala differentially mediate the anxiolytic effects of benzodiazepines. Brain Research, 638: 295-301.

Pesold C e Treit D (1995). The central and basolateral amygdala differentially mediate the anxiolytic effects of benzodiazepines. Brain Research, 671: 213-221.

Pesold C e Treit D (1996). The neuroanatomical specificity of the anxiolytic effects of intraseptal infusions of Midazolam. Brain Research, 710: 161-168.

Poplawski A e Johnson DA (1973). Open - field social behavior of rats following lateral or medial septal lesions. Physiology and Behavior, 11: 845-854.

Pratt J A (1992). The neuroanatomical basis of anxiety. Pharmacological Therapeutics, 55: 149-181

Raisman G (1966). The connections of the septum. Brain, 89: 317-348.

Rawlins JNP e Olton DS (1982). The septo-hippocampal system and cognitive mapping. Behavioral Brain Research, 5: 331-358.

Rodgers RJ e Cole JC (1994). The elevated plus maze: Pharmacology, Methodology and Ethology. Em Cooper SJ e Hendric CA (editores), Ethology and Psychopharmacology. John Wiley \& Sons, New York. p. 9-43.

Rodgers RJ e Johnson NJ (1995). Factor analysis of spatiotemporal and ethological measures in the murine elevated plus maze test of anxiety. Pharmacology Biochemistry and Behavior, 52: 297-303. 
Rodgers RJ, Cao BJ, Dalvi A e Holmes A (1997). Animal models of anxiety: an ethological perspective. Brazilian Journal of Medicine and Biological Research, 30: 289-304.

Rodgers RJ, Johnson NJ, Cole JC, Dewar CV, Kidd GR e Kimpson PH (1996). Plus-maze retest profile in mice: Importance of initial stages of trial 1 and response to post-trial cholinergic receptor blockade. Pharmacology Biochemistry and Behavior, 54: 41-50.

Saper CB (1984). Organization of cerebral cortical afferent systems in the rat: I. Magnocellular Basal Nucleus. The Journal of Comparative Neurology, 222: 313-342.

Setem J (1997). Análise etofarmacológica de ligantes serotoninérgicos em ratos testados no labirinto em cruz elevado. Dissertação de mestrado apresentada à Universidade de São Paulo: 4.

Shen J, Barnes CA, Wenk GL e McNaughton BL (1996). Differential effects of selective immunotoxic lesions of medial septal cholinergic cells on spatial working and reference memory. Behavioral Neuroscience, 110: 1181-1186.

Stackman RW e Walsh TJ (1995). Anatomical specificity and time-dependence of chlordiazepoxideinduced spatial memory impairments. Behavioral Neuroscience, 109: 436-445.

Stackman, R.W., Walsh, T.J., Brucato, F.H., and Swartzwelder, H.S. Medial septal benzodiazepine receptors modulate hippocampal synaptic plasticity. Brain Res 717:12-21, 1996.

Swanson LW (1978). The anatomical organization of septo-hippocampal projections. Em Weiskrantz L (editor), Functions of the septo-hippocampal system. Elsevier, Amsterdx. p. 25-44.

Swanson LW, TeylerTJ e Thompson RF (1982). Hippocampal long term potentiation: Mechanisms and implications for memory. Neuroscience Research Program Bulletin, 20: 603-764.

Taylor P (1996). Anticholinesterase agents. Em Hardman JG, Gilman AG e Limbird LE (eds), Goodman \& Gilman's The Pharmacological Basis of Therapeutics. McGraw-Hill, Nova York: 161-163.

Thompson WR e Solomon LM (1954). Spontaneous pattern discrimination in the rat. Journal of Physiological Psychology, 47: 104-107.

TomazC, Anson H, McGaugh JL, Souza-Silva MA, Viana MB e Graeff FG (1993). Localization in the amygdala of the amnestic action of diazepam on emotional memory. Behavioral Brain Research, 58: 99-105.

Torres EM, Perry TA, Blokland A, Wilkinson LS, Wiley RG, Lappi DA e Dunnett SB (1994). Berhavioral, histochemical and biochemical consequences of selective immunolesions in discrete regions of the basal forebrain cholinergic system. Neuroscience, 63: 95-122.

Treit D (1985). Animal models for the study of anti-anxiety agents: a review. Neuroscience and Biobehavioral Reviews, 9: 203-222.

Treit D (1994). Animal models of anxiety and anxiolytic drug action. Em Denboer JA e Ad Sitzen JM (editores), Handbook of Depression and Anxiety: A Biological approach. Marsel Decker, New York. p. 201-24.

Treit D e Menard J (1997). Dissociations among the anxiolytic effects of septal, hippocampal and amygdaloid lesions. Behavioral Neuroscience, 111: 653-658.

Treit D e Pesold C (1990). Septal lesions inhibit fear reactions in two animal models of anxiolytic drug action. Pharmacology Biochemistry and Behavior, 47: 203-205.

Vanucchi MG, Scali C, Kopf SR, Pepeu G e Casamenti F, (1997). Selective muscarinic antagonists differentially affect in vivo acetylcholine release and memory performances of young and aged rats. Neuroscience, 79: 837-846.

Viana MB, Graeff FG e Loschmann PA (1997). Kainate microinjection into the dorsal raphe nucleus induces 5-HT release in the amygdala and periaqueductal gray. Pharmacology Biochemistry and Behavior, 58: 167-172.

Vinagranova OS (1995). Expression, control and probable functional significance of the neuronal theta rhythm. Progress in Neurobiology, 45: 523-583.

Waite JJ, Wardlow ML, Chen AC, Lappi DA, Wiley RG e Thal LJ (1994). Time course of cholinergic and monoaminergic changes in rat brain after immunolesioning with 192-IgG-Saporin. Neuroscience letters, 169: 154-158. 
Walsh TJ e Chrobak JJ (1991). Animal models of Alzheimer's disease: Role of hippocampal cholinergic systems in working memory. Em Dachowski L e Flaherty C (eds), Current Topics in Animal Learning: Brain, Emotion, and Cognition. Lawrence Erlbaum, Nova Jersey: 347-379.

Walsh TJ, Gandhi C e Stackman RW (1998). Reversible inactivation of the Medial Septum or Nucleus Basalis impairs working memory in rats: A dissociation of memory and performance. Behavioral Neuroscience, 112: 1114-1124.

Walsh TJ, Herzog CD, Gandhi C, Stackman RW e Wiley RG (1996). Injection of IgG-192-Saporin into the medial septum produce cholinergic hypofunction and dose-dependent working memory deficits. Brain Research, 726: 69-79.

Walsh TJ, Stackman RW, Emerich DF e Taylor LA (1993). Intraseptal injection of GABA and benzodiazepine receptor ligands alters high - affinity choline transport in the hippocampus. Brian Research Bulletin, 31: 267-271.

Wenk GL (1997). The Nucleus Basalis Magnocellularis cholinergic system: One hundred years of progress. Neurobiology of Learning and Memory, 67: 85-95.

Whitehouse PJ, Price DL, Struble RG, Clark AW, Coyle JT e Delong MR (1982). Alzheimer's disease and senile dementia: loss of neurons in the basal forebrain. Science, 215: 1237-1239.

Wiley RG, Berbos TG, Deckwerth TL, Johnson EM e Lappi DA (1995). Destruction of the cholinergic basal forebrain using immunotoxin to rat NGF receptor: Modeling the cholinergic degeneration of Alzheimer's disease. Journal of the Neurological Sciences, 128: 157-166.

Wiley RG, Oeltmann TN e Lappi DA (1991). Immunolesioning: selective destruction of neurons using immunotoxin to rat NGF receptor. Brain Research, 562: 149-153.

Winson J (1978). Loss of hippocampal theta rhythm results in spatial memory deficit in the rat. Science, 201: 160-163.

Yadin E, Thomas E, Grishkat L e Strickland C (1992). The role of the lateral septum in anxiolysis . Physiology and Behavior, 53: 1077-1083.

Zangrossi JH e Graeff FG (1994). Behavioral effects of intra-amygdala injections of GABA and 5-HT acting drugs in the elevated plus maze. Brazilian Journal of Medicine and Biological Research, 27: 2453-2457.

Zimbardo PG e Montgomery KC (1957). The relative strengths of consummatory responses in hunger, thirst, and exploratory drive. Journal of Comparative Physiological Psychology, 50: 504-508. 